\title{
Allergic contact dermatitis: epidemiology, molecular mechanisms, in vitro methods and regulatory aspects
}

\author{
Current knowledge assembled at an international workshop at BfR, Germany
}

\author{
M. Peiser • T. Tralau • J. Heidler • A. M. Api • J. H. E. Arts • D. A. Basketter • J. English • T. L. Diepgen • \\ R. C. Fuhlbrigge $\cdot$ A. A. Gaspari · J. D. Johansen · A. T. Karlberg • I. Kimber · J. P. Lepoittevin $・$ \\ M. Liebsch • H. I. Maibach - S. F. Martin • H. F. Merk • T. Platzek • T. Rustemeyer • A. Schnuch • \\ R. J. Vandebriel $\cdot$ I. R. White $\cdot$ A. Luch
}

Received: 14 June 2011/Revised: 29 August 2011/Accepted: 20 September 2011/Published online: 14 October 2011

(C) The Author(s) 2011. This article is published with open access at Springerlink.com

\begin{abstract}
Contact allergies are complex diseases, and one of the important challenges for public health and immunology. The German 'Federal Institute for Risk Assessment' hosted an 'International Workshop on Contact Dermatitis'. The scope of the workshop was to discuss new discoveries and developments in the field of contact dermatitis. This included the epidemiology and molecular biology of contact allergy, as well as the development of new in vitro methods. Furthermore, it considered regulatory aspects aiming to reduce exposure to contact
\end{abstract}

M. Peiser · T. Tralau $(\bowtie) \cdot$ J. Heidler .

T. Platzek $\cdot$ A. Luch $(\bowtie)$

Department of Product Safety, German Federal Institute for Risk

Assessment (BfR), Thielallee 88-92, 14195 Berlin, Germany

e-mail: Tewes.Tralau@bfr.bund.de

A. Luch

e-mail: Andreas.Luch@bfr.bund.de

\section{A. M. Api}

Research Institute for Fragrance Materials,

Hackensack, NJ, USA

J. H. E. Arts

AkzoNobel N.V., Arnhem, The Netherlands

D. A. Basketter

DABMEB Consultancy Ltd, Sharnbrook, UK

J. English

Nottingham University Hospitals, Nottingham, UK

T. L. Diepgen

Department of Social Medicine,

Occupational and Environmental Dermatology,

University of Heidelberg, Heidelberg, Germany

R. C. Fuhlbrigge

Harvard Skin Disease Research Center, Boston, MA, USA sensitisers. An estimated 15-20\% of the general population suffers from contact allergy. Workplace exposure, age, sex, use of consumer products and genetic predispositions were identified as the most important risk factors. Research highlights included: advances in understanding of immune responses to contact sensitisers, the importance of autoxidation or enzyme-mediated oxidation for the activation of chemicals, the mechanisms through which hapten-protein conjugates are formed and the development of novel in vitro strategies for the identification of skin-sensitising chemicals. Dendritic cell cultures and structure-activity

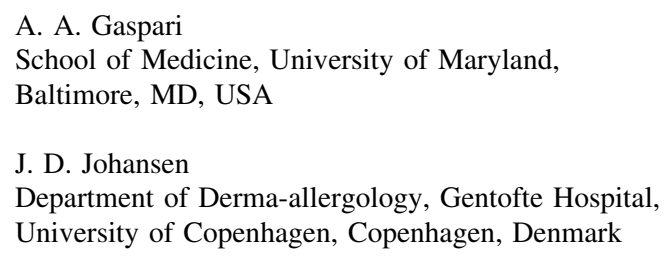

J. D. Johansen

Department of Derma-allergology, Gentofte Hospital,

University of Copenhagen, Copenhagen, Denmark

\section{A. T. Karlberg}

Department of Chemistry, Dermatochemistry and Skin Allergy,

University of Gothenburg, Gothenburg, Sweden

I. Kimber

Faculty of Life Sciences, University of Manchester,

Manchester, UK

\section{J. P. Lepoittevin}

Dermatochimie, University of Strasbourg,

Strasbourg, France

M. Liebsch · A. Luch

Department of Experimental Toxicology and ZEBET,

Center for Alternatives to Animal Testing, German Federal

Institute for Risk Assessment (BfR), Berlin, Germany

H. I. Maibach

Department of Dermatology, University of California San

Francisco, San Francisco, CA, USA 
relationships are being developed to identify potential contact allergens. However, the local lymph node assay (LLNA) presently remains the validated method of choice for hazard identification and characterisation. At the workshop the use of the LLNA for regulatory purposes and for quantitative risk assessment was also discussed.

Keywords Contact allergy - Dermatitis - Epidemiology · Molecular mechanisms $\cdot$ Regulatory aspects

\section{Introduction}

The prevalence of contact allergy is rising worldwide [13]. This results in high costs for health care systems and the economy as well as in an impairment of the quality of life for the patients. The German 'Federal Institute for Risk Assessment' (BfR) invited national and international experts from the field of contact dermatitis for a 2-day workshop in Berlin, Germany. The workshop was organised as a part of the 'action plan against allergies', initiated by the German 'Federal Ministry of Food, Agriculture and Consumer Protection' (BMELV). The aim of the workshop was to provide a better understanding of allergic skin reactions by summarising the current state of research and to elucidate prevention strategies, as well as the requirement for any further regulation. The first day emphasised the magnitude of the problem in the general population, highlighted possible prevention strategies, and summarised known cellular and molecular mechanisms of contact allergy. The second day focused on new in vitro methods for assessing allergen potency and on regulatory aspects of contact allergy.

\section{S. F. Martin}

Allergy Research Group, Department of Dermatology,

University Medical Center Freiburg, Freiburg, Germany

H. F. Merk

Department of Dermatology and Allergology,

University Hospitals Aachen, Aachen, Germany

T. Rustemeyer

VU University Medical Center, Amsterdam,

The Netherlands

\section{A. Schnuch}

Department of Dermatology, University of Göttingen,

Göttingen, Germany

R. J. Vandebriel

National Institute for Public Health and the Environment, Bilthoven, The Netherlands

I. R. White

St. John's Institute of Dermatology, St. Thomas' Hospital, London, UK
The epidemiology of contact dermatitis: prevalence, correlations and molecular markers

\section{Allergy incidence and prevalence}

In Europe about $20 \%$ of the general population suffers from contact allergy to at least one contact allergen. Most common are allergies to nickel, fragrances and preservatives. Allergic reactions to chromate and $p$-phenylenediamine (PPD) are generally less common but occur frequently in occupationally exposed subgroups of the population [4]. Contact dermatitis occurs twice as frequently in women as in men [4] and often starts at a young age, with a prevalence of $15 \%$ in $12-16$ year olds (Fig. 1) [5].

Of major concern is occupational contact dermatitis (OCD), which ranks first among occupational diseases in many countries [6]. The reported annual incident rate for OCD is $0.5-1.9 \%$ [7]. However, incidences are likely to be underestimated because of underreporting and lacking registration for milder cases of skin disease [8]. Moreover, the notification systems differ amongst countries, as do the criteria for compensation. In a Bavarian study, about a third of patients registered with OCD were severely professionally affected, facing either retraining or unemployment. The most affected professions $(\sim 80 \%)$ were metal workers, hairdressers, health care workers, employees in the food industry, cleaners, construction workers and painters [9].

Nickel Nickel is one of the major contact allergens worldwide. Therefore, the European Union (EU) restricted its use in consumer products in 1994 [10]. As a result nickel allergy among young patients showed a decline in several countries such as Germany [11], Sweden [12] and Denmark [13]. In Denmark the frequency of nickel allergies dropped from $26.9 \%$ before the EU directive to $12.4 \%$ thereafter [13]. However, despite the initial decline nickel sensitisation is still frequent among young women in Germany, probably due to insufficient protection [14]. Further on a significant number of people are still exposed to nickel, mainly in their working environment [15] and new sources of nickel exposure, such as mobile phones, have been reported recently [16]. Nevertheless, in the absence of legislative regulation for the use of nickel (e.g. in the US) the prevalence of nickel allergy is still increasing, especially among women [1].

Fragrances Fragrance allergy is among the most frequently detected allergies in the general population and has a prevalence ranging from $1.0-4.2 \%$ [17]. About a third of all allergies against cosmetic products are caused by fragrance allergies. Fragrances are complex mixtures 
comprising altogether more than 2,000 substances, many of which are contact allergens. A mix of eight substances, fragrance mix I, has routinely been used to detect fragrance-mediated contact dermatitis. This mix has now been supplemented with a second mix of five compounds, called fragrance mix II [18]. Recent years saw a decline in allergy prevalence against fragrance mix I. Nevertheless, there remain a high number of reported cases with acute eczemas caused by fragrances [19-21]. The frequency of fragrance allergies is increased further by the autoxidative formation of allergens from commonly used fragrances [22-24].

A fragrance allergen with increasing prevalence is hydroxyisohexyl 3-cyclohexene carboxaldehyde (HICC). It is extensively used in deodorants [25] and has been linked to strong allergic reactions in users [26]. Hence HICC is now one of 26 fragrance chemicals recognised as contact allergens that is required to be labelled when present in cosmetic products and detergents (household products) [27]. This list is currently being reviewed.

Chromium Contact dermatitis against chromium $\left(\mathrm{Cr}^{\mathrm{VI}}\right)$ has been a recognised problem in the occupational setting, with a prevalence of e.g. $17 \%$ in cement workers during the construction of the channel tunnel connecting continental Europe with Britain [28]. Therefore, the EU regulated the content of chromium in cement in 2005 and sensitisation to chromate in construction workers has since declined [29, 30]. However, this regulation does not include leather products such as shoes, where an increasing incidence has been recognised [31]. In Germany, though, the sale of consumer products with skin contact is banned if they release detectable amounts of $\mathrm{Cr}^{\mathrm{VI}}$ (ordinance of commodities).

p-Phenylenediamine (PPD) Allergic reactions caused by oxidative hair dye ingredients (e.g. PPD) are of special concern because of their severity and the widespread use of hair dyes. An estimated $0.2-2.5 \%$ of the European population and up to $20 \%$ of hairdressers suffer from hair dye allergies [32]. One risk factor for sensitisation to PPD in the general population is black henna tattoos with illegally added PPD [33-35]. Of further concern are cross-reacting substances closely related to PPD, such as the hair dye toluene-2,5-diamine (PTD) or the antioxidant isopropylphenyl $p$-phenylenediamine (IPPD) [36].

\section{Risk factors}

Risk factors for allergic contact dermatitis (ACD) can be subdivided into acquired and inherent. Acquired risk factors are generally inflammatory skin diseases such as irritant contact dermatitis (ICD), stasis dermatitis and possibly atopic dermatitis, while inherent risk factors are

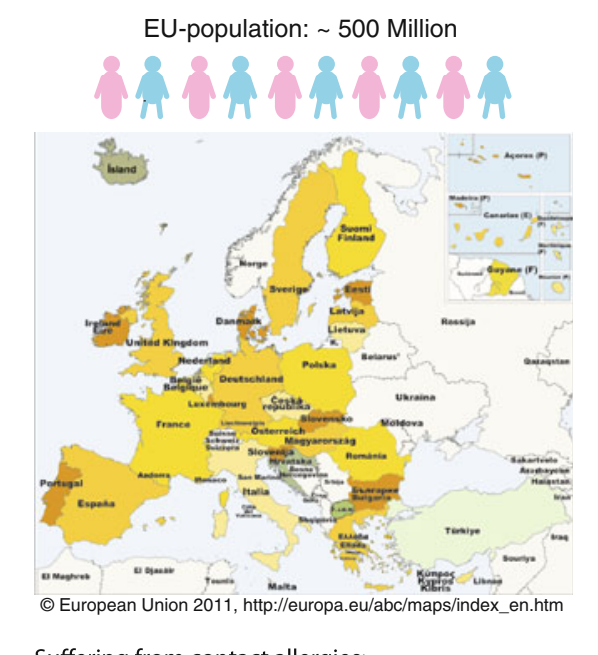

Suffering from contact allergies:
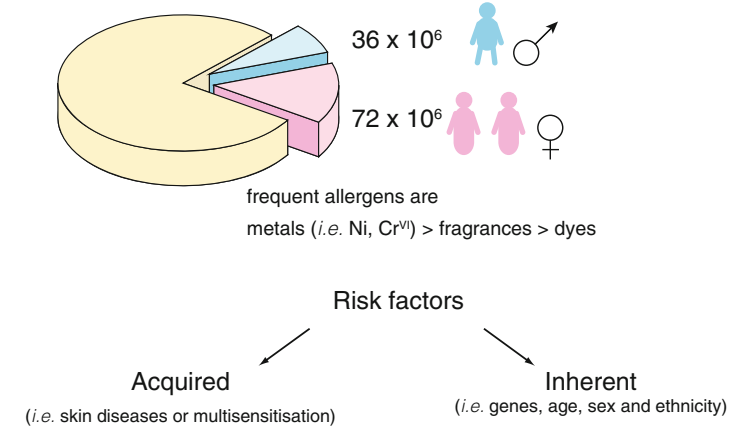

(i.e. skin diseases or multisensitisation)

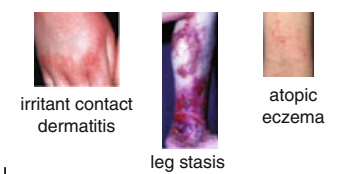

Prevention of dermatitis in the occupational setting by surveillance, introduction of good working practices (e.g. hair dressers) and legislation (e.g. European nickel directive and limits for chromium in cement).

Fig. 1 Allergic contact dermatitis in the European Union, incidence and preventive measures

genetic variances resulting in a higher susceptibility (Fig. 1).

Acquired risk factors ICD often precedes ACD. Usually ICD results from a breakdown of the barrier function of the skin after exposure to skin irritants. Approximately $10 \%$ of the population suffer from ICD. The most common causes are wet work, hand washing and the wearing of occlusive rubber gloves. Atopy is a well recognised risk factor for ICD and thus possibly also for ACD [37]. However, recent studies on the gene polymorphisms of filaggrin published conflicting results regarding the question if ICD is a purely acquired risk factor [38, 39]. It seems likely that ICD has an inherent basis [40, 41].

Stasis (or leg) dermatitis is caused by venous insufficiency rather than allergens. Nevertheless, after adjusting for confounders such as sex, age and atopic dermatitis, leg 
stasis could be identified to increase the risk for ACD against distinct allergens significantly [42]. Another independently acquired risk factor that was identified by regression analysis is multisensitisation. The risk of contact allergy to a specific allergen increases with the number of positive reactions in patch testing [43]. It was further shown that polysensitised individuals reveal stronger reactions to patch tests [44] and that there is an association between polysensitisation and sensitisation to weak allergens [45].

A further potential risk factor is atopic eczema, which often results in a reduced skin barrier function and therefore facilitates the penetration of toxins and allergens. However, differences in the immunological response in patients with atopic eczema frequently seems to mitigate some of the observed effects [46].

Inherent risk factors Genes, age, sex and ethnicity are the main inherent risk factors in regard to susceptibility for ACD.

Genetic risk factors are based on variations in genes (e.g. polymorphisms) involved in relevant steps for the development of contact dermatitis. Genetically influenced steps are the antigen uptake through the skin barrier, the antigen-specific response by immune cells or the metabolism of antigens by cutaneous enzymes [for a comprehensive review refer to ref. 47]. An example for the latter is the metabolism and possible activation of antigens by epidermal $\mathrm{N}$-acetyltransferases (NATs). Studies found a relationship between the genetic polymorphism for these phase II enzymes and the risk for contact dermatitis. Patients with contact dermatitis tended to have NATs with a higher than average enzymatic activity $[48,49]$. Other studies link the allele for a rapid acetylating NAT1 to a lower susceptibility for PPD sensitisation [50]. Similarly, a homogenous deletion of the glutathione $S$ transferases (GSTs) M1 and T1 showed an association with increased sensitisation against the preservative thimerosal [51]. The role of GSTs was confirmed in another study showing an elevated risk for chromate sensitisation in cement workers with a GST-T1 null phenotype [52]. Cytokine gene polymorphisms represent possible genetic risk factors at the level of an immunologic response [53]. Mutation of the promoter for tumour necrosis factor $\alpha$ at position 308 is associated with a higher susceptibility for chromate sensitisation in cement workers [52]. Likewise, the homozygous allele interleukin (IL) $16^{-295 \mathrm{C}}$ is found more frequently in polysensitised individuals with ACD [54]. Other gene polymorphisms increasing the risk for ACD have been observed in coding regions of enzymes, i.e. angiotensin-converting enzyme [55]. Induction and elicitation of contact dermatitis decline with increasing age [due reduced immune functions, see ref. 56], whereas the frequency of sensitisation increases [42].
The sex prevalence of ACD in the German population is reported to be $8 \%$ in men and $21 \%$ in women [57]. The more than two-fold higher prevalence in women is due to different exposures, such as nickel through piercing [13, 58]. However, even if nickel is not considered, women still have a higher prevalence for ACD. This higher susceptibility is probably caused by hormonal influences [59, 60]. Boys on the other hand show a higher prevalence for allergic skin reactions against fragrances [61].

Studies investigating the relation between ACD and ethnicity are inconclusive in regard to ethnicity as an inherent risk factor [e.g. ref. 62]. Some reports implicate darker skin to have a higher barrier function for some substances, thus lowering the respective risk for ACD [63, 64].

Risk factors in the occupational setting Atopic skin diathesis (ASD) was recognised as a major risk factor for OCD [65]. Data analysed from a registry of occupational skin diseases in Bavaria showed that $37 \%$ of patients with OCD also suffered from ASD [66]. Cohort studies subsequently identified several professional risk factors for the development of OCD. In the car industry the most important risk factors were ASD, a history of hand eczema and more than $3 \mathrm{~h}$ wet work per day [67]. Likewise hairdressers were significantly affected, with 59\% developing hand eczema during their first year of apprenticeship. Again, ASD and wet work $(4 \mathrm{~h})$ were identified as the statistically most significant risk factors $(p<0.001$, T.L.D., personal communication).

Similar results come from studies with nurses, where ASD together with hand washing and disinfection was a significant risk factor $(p<0.001)$ for the development of hand eczema (T.L.D., personal communication). This is in line with the findings of studies looking into the causes of a recent epidemic of ICD in health care workers in the UK's national health system (NHS). Health care workers in the UK wash their hands up to 60 times a day as a result of the NHS' 'Clean Hands Campaign', which was introduced to reduce microbial cross infections, especially with multidrug resistant Staphylococcus aureus. As a result there has been a two-fold increase in the amount of hand cleansing soap purchased by the NHS in the past 4 years, while the amount of alcohol gel purchased is a tenth of what health care providers in continental Europe tend to use. In order to lower the risk for ICD, educational hand cleansing campaigns should thus emphasise the need to use alcohol gels rather than hand washing (J.E., personal communication).

\section{Prevention}

Surveillance is the basis of prevention [68], and therefore population-based investigations in consumer and 
occupational settings are important. However, they cannot provide a tool for continuous monitoring. They have to be complemented by clinical epidemiological data, which indeed are collected in many countries. This has previously been the basis for successful interventions such as the nickel regulation [10] or the ban of the preservative methyldibromo glutaronitrile (MDGN) [69].

Prevention of $O C D$ Occupational contact dermatitis frequently occurs because of lack of awareness of dermatitis hazards, complacency and poor working practices. There are various approaches to prevent OCD. Generally speaking 'general primary prevention', that is the elimination, replacement or reduction of allergenic substances, is by far the most effective approach [e.g. 36, 70]. Alternatively, exposure to harmful substances could be minimised by avoiding their release from the corresponding product, e.g. by encapsulation. Other preventive measures include the reorganisation of work, for example reducing the hours of wet work in order to minimise the risk for hand eczema (Fig. 1).

Efforts to minimise risk factors for OCD should be complemented by the use of personal protective equipment and pre-employment screening. In Germany, prevention measures are described in the "Approved Code of Practice" (TRGS) regulations. For hairdressers these include the replacement of harmful substances und instructions on the use of personal protective equipment (e.g. gloves). As a result the annual incidence of OCD in hairdressers dropped significantly [70, 71]. Skin care management should include preventive skin protection as well as skin care after hand cleansing [72]. Recommendations for the minimisation of work-related hand eczema include the washing of the hands with lukewarm water, the use of appropriate gloves for the shortest possible time, the removal of hand jewellery prior to work, the wearing of cotton liners when possible and the avoidance of disinfectant hand cleansers. Creams should be applied after work and at home [73].

\section{Molecular mechanisms of chemically induced contact dermatitis}

Innate immune mechanisms involved in contact dermatitis

Dendritic cells (DCs) and the local tissue microenvironment are crucial factors in the development of ACD. Within the immune system DCs are the cell type that primes naïve $\mathrm{T}$ cells and thus forms a crucial link between the innate and adaptive immune system.

The precise role of DCs in ACD is still under investigation; especially the contributions of the respective cellular pools are still disputed. In the current model Langerhans cells (LCs), as epidermal DCs, and dermal DCs are centrally involved in the sensitisation and the elicitation phases of ACD (Fig. 2). During sensitisation, DCs react to potentially allergic chemicals by interaction with neighbouring keratinocytes, migration to the local draining lymph nodes and the priming of naïve $\mathrm{T}$ cells. These reactions are mediated by inflammatory cytokines, chemokines and adhesion molecules [74]. Allergen-specific effector $\mathrm{T}$ cells are then recruited into the skin upon contact with the same allergen (elicitation). Following their recruitment these $\mathrm{T}$ cells are activated by allergen-presenting skin cells, including LCs, dermal DCs and most likely keratinocytes [75]. Cytotoxic effector $\mathrm{T}$ cells in the epidermal-dermal border then deliver an inflammatory 'lethal hit' killing, amongst others, keratinocytes at the suprabasal layer [76]. The following activation of further skin-specific effector cells, i.e. cytotoxic $\mathrm{T}\left(\mathrm{CD}^{+} \mathrm{Tc} 1\right)$ cells and $\mathrm{T}$ helper (Th) cells 1 and 17, results from the interaction of DCs, keratinocytes and the loss of regulatory $\mathrm{T}\left(\mathrm{T}_{\text {reg }}\right)$ cell-mediated inhibition [77, 78].

The priming of naïve $T$ cells in skin is the result of a molecular signal cascade originating from skin DCs. The latter present antigenic peptides or allergens on their major histocompatibility complex molecules (MHC) for recognition by antigen specific $\mathrm{T}$ cell receptors (TCRs). Concomitantly there is co-stimulation of the $\mathrm{T}$ cell population, e.g. by the interaction of DC-expressed CD80/CD86 and CD28 on T cells. Cytokines excreted by the DCs (e.g. IL-12, IL-6) polarise the T cell subset differentiation. This leads to the loss of regulatory $\mathrm{T}$ cell inhibition, as well as the generation of Th cells 1, 2, 3 and $17, \mathrm{CD}^{+} \mathrm{Tc} 1$ cells and most likely other subsets. Finally the expression of $\mathrm{T}$ cell homing receptors (e.g. E-selectin ligand, CCR4 and CCR10) is induced by migratory DCs in the draining lymph nodes. Primed T cells will subsequently home into the tissue of origin of the corresponding DCs, e.g. the skin in case of dermal DCs and LCs $[79,80]$. Skin DCs acquire their potential to imprint tissue-specific homing receptors in $\mathrm{CD}^{+} \mathrm{Tc} 1$ cells by interaction with stromal and epithelial cells. In cocultures of DCs with dermal fibroblasts, DCs are prompted to imprint skin homing receptors on $\mathrm{T}$ cells [81].

In humans $A C D$ has been associated with defective $T_{\text {reg }}$ cells $[82,83]$ and indeed it has become clear that $T_{\text {reg }}$ cells influence sensitisation as well as elicitation. Originally $\mathrm{T}_{\mathrm{reg}}$ cells were defined as $\mathrm{CD} 4{ }^{+} \mathrm{CD} 25^{+}-\mathrm{T}$ cells and were mainly associated with self-tolerance [84, 85]. We now know that this definition comprises a heterogeneous cell population that includes natural $T_{\text {reg }}$ and inducible $T_{\text {reg }}$ cells under the transcriptional control of Foxp3 as well as Tr1- and Th3-cells [reviewed in refs. 86, 87]. The skin contains predominantly inducible $\mathrm{T}_{\text {reg }}$ cells, which can be triggered by LCs as well as dermal DCs $[88,89]$. However, the precise phenotypes of $\mathrm{T}_{\text {reg }}$ cells involved in ACD are 
still not known [87]. Recently the induction of contact allergen-specific $\mathrm{CD}^{+}{ }^{+} \mathrm{CD} 25^{+} \mathrm{ICOS}^{+} \mathrm{T}_{\text {reg }}$ cells during sensitisation was shown to be an important regulator of $\mathrm{CD}^{+}$effector $\mathrm{T}$ cell responses in contact hypersensitivity [90]. Following exposure to a contact allergen $\mathrm{T}_{\text {reg }}$ cells can lower or even completely suppress the process of sensitisation [89, 91-93]. During subsequent elicitation they can further downregulate the immune response (i.e. by CD39) and influence the influx of leukocytes (mediated by IL-10) [94, 95]. Finally, $\mathrm{T}_{\text {reg }}$ cells are involved in the control and eventually termination of the inflammatory response [96].

The innate stress and immune response preceding the induction of skin homing $\mathrm{T}$ cells is triggered by several complex interactions of contact allergens with the skin and partly resembles the innate immune response to pathogens. This involves the triggering of Toll-like receptors, induction of reactive oxygen species and activation of the NLRP3 inflammasome [97]. As a cytosolic complex the latter consists of the innate immune receptor NLRP3, the adaptor protein ASC and pro-caspase-1. Its activation is the result of allergen-induced ATP-release from skin cells and triggering the ATP receptor $\mathrm{P}_{2} \mathrm{X}_{7}$ [98-100]. Subsequently this leads to release of active caspase-1, which processes contact allergen-induced proIL- $1 \beta$ and pro-IL-18 to the mature and secreted cytokines. These cytokines are involved in the inflammation of the skin and trigger migration of DCs, thus mediating a 'danger' signal function for contact sensitisers [101, 102]. Knock out studies in mice further confirm this signal function for contact sensitisers. Recent studies show that Toll-like receptor (TLR) deletion mutants ( $\Delta$ TLR $2 / \Delta T L R$ 4 or, alternatively, $\Delta$ TLR 2 or $4 / \Delta \mathrm{IL}-12 \mathrm{R} \beta 2$ ) can not be sensitised to 2,4,6-trinitro-1-chlorobenzene (TNCB) and other contact allergens. In the absence of TLR2- or TLR4mediated signalling DCs are only partially activated by contact allergens, upregulating co-stimulatory molecules but no pro-inflammatory cytokines [103]. While TNCB activates TLR2 and TLR4 indirectly through the induction of endogenous TLR2/4 ligands, nickel can trigger TLR4 signalling directly. Nickel ions can interact with histidine residues in human TLR4. Interestingly, these histidine residues are missing in the mouse TLR4. This explains why mice do not develop contact hypersensitivity to nickel unless LPS is co-injected [104]. These new findings show a physiological role for TLRs in the induction of contact hypersensitivity.

Furthermore, contact allergens can induce the cytoprotective phase II response. The phase II response is activated by the binding of electrophilic contact allergens to the cysteine-rich sensor Kelch-like ECH-associated protein (Keap1). This results in the release and nuclear translocation of the transcription factor Nrf2, thereby leading to the activation of genes that contain antioxidant response elements [105]. Thus the Keap/Nrf2 pathway modulates inflammation and other responses of the cell. Contact sensitisers like 1-chloro-2,4-dinitrobenzene, $p$-phenylenediamine and $\mathrm{NiSO}_{4}$ are potent inducers of the Keap/Nrf2 pathway in DCs, suggesting Nrf2 may be a new biomarker for the sensitisation potential of chemicals [106].

The detailed understanding of the induction of innate stress and immune responses by contact allergens will help to develop new therapeutic strategies to treat $\mathrm{ACD}$, to identify potential contact allergens and to discriminate them from irritants. Another goal is to develop in vitro assays for hazard identification and risk assessment in order to replace animal testing.

The skin immune system and contact dermatitis: role of keratinocytes and NKT cells

Until recently the classical paradigm stated LCs to be the primary antigen presenting cells for $\mathrm{T}$ cell responses in skin. The importance of LCs being undisputed, this statement had to be revised to include the aforementioned DCs and, most likely, keratinocytes. Meanwhile there has been increasing evidence that LCs might also control the $\mathrm{T}$ cell response by secretion of anti-inflammatory cytokines (IL10 and TGF- $\beta$ ) and the induction of regulatory T cells [88, 107, 108]. Accordingly, following treatment with oxazolone or 2,4-dinitro-1-fluorobenzene (DNFB) mice with ablated LCs show increased ear swelling [109].

In this context keratinocytes may as well play an important role in downregulating the skin's immune responsiveness in steady state and may interfere with the induction of contact hypersensitivity. Only low levels of the inflammation-stimulating ligand B7 are expressed by keratinocytes during steady state. However, elevated levels of B7-1 (CD80) were found in keratinocytes transfected with B7-1 reporter constructs after exposure to allergens like oxazolone, Myroxylon pereirae (Balsam of Peru) or nickel chloride [110]. Keratinocytes from transgenic mice (B7-1 and B7-2) delivered costimulating signals for skin inflammation during ACD. After treatment with TNCB or DNFB, B7-1 transgenic mice showed pronounced ear swelling and elevated levels of the cytokines IL- 6 , TNF- $\alpha$ and LT- $\beta$. Furthermore, the expression of IL-10 and the hapten specific $\operatorname{IgE}$ is seen in B7-1 transgenic mice but absent in B7-2 (CD86) or wild-type (wt) mice. This inflammatory response is typical for Th1 reactions in chronic dermatitis [111]. The elicitation of ear swelling by the hapten-specific IgE indicates a deviated Th2-mediated immune response, even in the presence of Th1 specific cytokines $[111,112]$. In $w t$ mice keratinocytes thus seem to modulate $\mathrm{T}$ cell-mediated inflammation and induce immune tolerance by $\mathrm{T}$ cell anergy. 


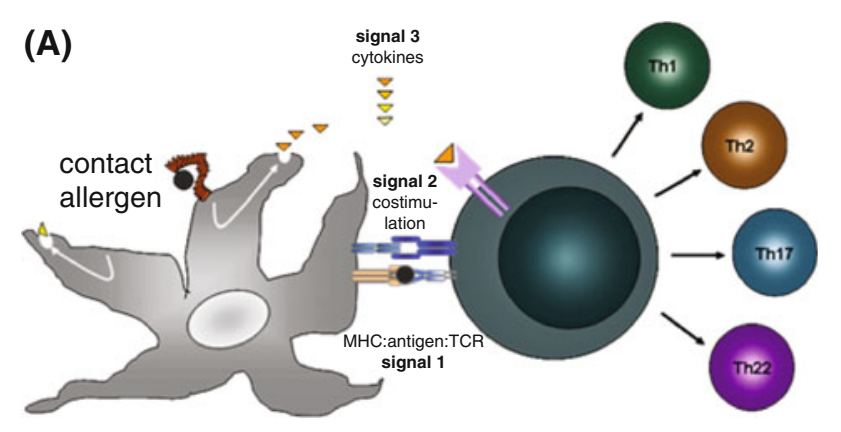

(B)

dendritic cell naïve Th cell polarised Th cell skin cells presenting peptide on MHC

Fig. 2 Lymphocyte-mediated immune mechanisms in contact allergy. Sensitisation phase (a). The contact allergen activates dendritic cells in the skin via 'pattern recognition receptors' such as TLRs. Subsequently naïve $\mathrm{T}$ helper (Th) cells are polarised upon specific recognition of the haptenated allergen by the major

Further, keratinocytes are most likely the main source of IL-33 in the epidermis. This proinflammatory member of the IL-1 family is found in high concentrations in barrier tissues [113-115]. Located in the nuclear compartment of keratinocytes IL-33 is discussed to be an alarmin released by necrotic cells and was found to exacerbate contact sensitivity $[113,116]$. The precise function of IL-33 is unkown. However, IL-33 is known to activate the ST2$1 \mathrm{RAcP}$ receptor complex, thus triggering activation of NF$\kappa \mathrm{B}[117,118]$. Further on IL-33 was found to enhance IL-5 production by Th2 cells and to induce the proliferation of B1 lymphocytes independent of IL-5. The respective studies indicate both effects to be ST2-mediated [116, 119]. The IgM secreted by B1 cells is not only reactive to a broad range of antigens, but also is required for the initiation of antigen specific T-cell migration [74, 116]. B1 B cells have been shown to participate in the early initiation phase of contact hypersensitivity by IgM-mediated facilitation of effector $\mathrm{T}$ cell recruitment for elicitation. Sensitisation with a contact allergen leads to rapid activation of natural killer $\mathrm{T}$ lymphocytes (NKT cells) in the liver. These then activate peritoneal B1 B cells via IL4, recruiting them to lymphoid organs [120-122].

Natural killer T lymphocytes are known to be crucial for autoimmune diseases, allograft rejection, anti-tumor immune responses and anti-microbial immunity. It remains to be determined if they contribute to the molecular mechanisms of ACD as well. In humans these lymphocytes recognise glycolipid antigens using a TCR composed of $\mathrm{V} \beta 24-\mathrm{J} \alpha 15$ and $\mathrm{V} \alpha 11$. Recognised antigens can be either self-antigens or microbial antigens and are presented by CD1d1. It was previously shown that terminally differentiated keratinocytes from human skin increase surface expression of CD1d [123]. A recent study examined skin biopsies from positively patch-tested patients using histocompatibility complex (MHC), costimulatory signals and cytokines such as IL-12, IL-4, IL-1 $\beta$ and IL-6. Elicitation phase (b). Hapten-specific cytotoxic $\mathrm{CD}^{+} \mathrm{T}$ lymphocytes (CTLs) release inflammatory cytokines and induce disease-specific local skin lesions following re-exposure of the skin to the same contact allergen

quantitative RT-PCR and immune histochemistry. Expression of CD1d and CD161 (NKR-P1A) was found to be upregulated in epidermal cells. The NKT frequency was determined by immunological detection of the V $\alpha 24$ TCR chain. Following exposure to $\mathrm{PPD}, \mathrm{NiSO}_{4}$ and epoxy resin NKT frequencies in ACD lesions were 2, 4 and 33\% respectively. In addition, the expression of the NKT cytokines IFN- $\gamma$ and IL-4 was upregulated. The occurrence of NKT in blood was constantly below $0.1 \%$, confirming the observed effects to be specific for the ACD lesions [124]. These data support the notion that keratinocytes actively influence $\mathrm{T}$ cell mediated allergic immune responses in the skin.

Cytochrome P450 in keratinocytes and antigen presenting cells

Numerous isoforms of cytochrome P450-dependent monooxygenases (CYPs) as well as various transport systems are expressed within the skin. The respective cells comprise skin cells and include keratinocytes as the major compartment of the epidermis as well as antigen-presenting cells such as monocytes or dendritic cells [125]. CYPs are heme-containing enzymes catalysing the oxidative conversion of a range of predominantly lipophilic molecules into species that are generally more reactive and/or hydrophilic (water soluble), thus facilitating phase II metabolism and subsequent excretion from the body. Keratinocytes express multiple enzymes belonging to CYP families 1,2 and 3, which are well known to metabolise xenobiotics. CYPs 1A1, 1B1, 2B6, 2E1, 3A5 and 4B1 were found to be constitutively expressed in skin-derived keratinocytes. In addition, expression of CYP3A4 was induced by dexamethasone and levels of CYP1A1 were elevated following induction with benzanthracene [126]. 
Exon arrays show different expression patterns for CYPs between skin and liver cells as well as for keratinocytes and monocyte-derived DCs. Especially CYP1B1 and CYP27A1 were primarily expressed in DCs [125].

Several studies looked at the transport systems of keratinocytes and antigen-presenting cells because of the inherent linkage between CYP catalysed metabolism and cell transport. Keratinocytes and liver cells show similar expression patters for their efflux transport systems while differing in the expression of influx systems [127]. However, keratinocytes and antigen-presenting cells exhibit a similar pattern of expression for their influx proteins and differ only slightly regarding their efflux proteins. Both cell types express organic anion-transporting polypeptides B, D and $\mathrm{E}$, the corresponding ATP-binding cassette $\mathrm{C}$ transporters and the multi-drug resistance-associated proteins 1 , 3, 4, 5 and 6 [128]. The inhibition of transport proteins influences the phenotype of DCs and possibly the differentiation of keratinocytes [129]. Furthermore transport efficiency can influence allergen exposure and thus sensitisation. The delayed efflux of eugenol metabolites leads to an increased IL-8 expression because of high internal eugenol concentrations [130]. Other substances require CYP-dependent activation in order to become allergens and thus provide conflicting data in vivo and in silico. For carvoxime in particular uptake and subsequent CYPdependent metabolism are regarded as prerequisite for skin sensitisation [131].

\section{Common chemicals form contact allergens by autoxidation}

Contact dermatitis caused by low molecular weight compounds requires the formation of antigenic hapten-protein complexes. The potential of a low molecular weight compound to become a hapten is thus determined by its chemical reactivity towards skin proteins. Some compounds will react directly (e.g. nickel), while others require activation, either metabolically inside the skin or externally [132]. The latter are classified either as pro- or prehaptens, depending on the mode of activation. Non-sensitising compounds that require metabolic activation are prohaptens, while prehaptens are compounds with no or low sensitising potential that are activated externally [133].

Examples for prehaptens are found among the unsaturated hydrocarbons and ethers such as common fragrance terpenes, diterpenes in colophony and ethoxylated surfactans. Patch tests revealed some of these substances to be potent skin sensitisers following their activation by autoxidation. Autoxidation of limonene (from citrus) and linalool (from lavender), two frequently used fragrances, results in the formation of the corresponding hydroperoxides [134-136]. Multicentre studies imply that oxidised limonene and oxidised linalool are among the most common causes for ACD, while the compounds themselves rarely cause sensitisation [22-24, 137, 138].

Prohaptens are metabolically activated in the skin and thus activation could vary depending on the individuals' enzymatic expression patterns. Well-known examples of prohaptens are cinnamyl alcohol (3-phenyl-2-propen-1-ol) and urushiols [139, 140]. Some compounds are prehaptens as well as prohaptens. Depending on the way of activation the resulting haptens can have different potentials for skin sensitisation. A well-studied example is the moderate sensitiser geraniol, which is used in the basic fragrance mix for the diagnosis of contact allergy. Studies showed it to act as a prehapten that is activated by autoxidation, as well as being a prohapten when activated by CYPs. The two major haptens formed by both processes are geranial and neral. However, autoxidation results in the additional formation of a sensitising hydroperoxide, while enzymatic activation produces sensitising epoxides and aldehydes [141, 142].

Considering the importance of oxidation for the formation of haptens autoxidation and CYP-mediated metabolism should be part of the hazard identification for potential contact allergens. This can be achieved by predicting autoxidation using structure activity relationships (SAR) and by in vitro CYP activity assays. A recently developed CYP cocktail is based on cutaneous CYP enzymes and thus allows studying part of the skin metabolism in vitro [143]. Furthermore, diagnosis of contact allergens should include patch tests with oxidised forms of the corresponding substances.

\section{Contact sensitisation: hazard identification, assessment of potency and opportunities for the development of alternative methods}

In the past decades hundreds of chemicals have been implicated as contact allergens. Hence there is a need to identify potential skin sensitisers. Most approaches are based upon an appreciation of the cellular and molecular mechanisms involved in the acquisition of skin sensitisation. LCs are of particular interest as they are now known to play important roles in both the initiation and orchestration of cutaneous immune responses to chemical allergens. The activation, mobilisation, migration and subsequent presentation of antigen in regional lymph nodes results in a clonal expansion of allergen-responsive $\mathrm{T}$ lymphocytes and the development of sensitisation [87, 144-148].

The activation and proliferation of $\mathrm{T}$ lymphocytes in skin-draining lymph nodes during skin sensitisation can be measured using the local lymph node assay (LLNA) [149]. In this assay cell turnover is measured as a function of the incorporation of ${ }^{3} \mathrm{H}$-thymidine. On this basis chemicals that elicit a three-fold or greater increase in $\mathrm{T}$ lymphocyte proliferation are categorised as skin sensitisers. The LLNA 
provides a reliable test for the identification of skin-sensitising chemicals and has been added to the OECD testing guidelines [guideline 429, see ref. 150]. In addition, the LLNA can be used for evaluation of the relative skinsensitising potency of contact allergens, and this in turn provides a sound basis for the development of accurate quantitative risk assessments. For this latter purpose EC3 values are derived from consideration of dose responses in the assay $[151,152]$.

The LLNA is the most useful tool for the identification and characterisation of skin-sensitising substances. However, there is a lack of comparable in vitro methods, and substantial efforts have been, and are being, made worldwide to develop alternative assays. The main challenge is to address the required level of integration of the molecular and cellular processes that are underlying skin sensitisation. The development of contact allergy follows a four-step process as the allergen has to (1) achieve epidermal bioavailability, (2) stimulate a local trauma that leads to cytokine expression, (3) form a hapten-protein conjugate and (4) be inherently immunogenic to induce the activation of $\mathrm{T}$ lymphocytes. It will probably take several separate in vitro assays to achieve a sufficient level of experimental integration for these steps (I.K., personal communication).

\section{In vitro methods as alternatives to animal testing in predicting and characterising the allergenic potency of chemicals}

\section{Characterising allergenic hazards and assessing allergy risks: defining the role of alternatives}

Adequate in vitro assays should allow the assessment of allergen potency, a requirement introduced in 2009 by the 'Globally Harmonised System' [153]. In the absence of an agreed standard data set, this will prove to be challenging as the dose metrics employed in vitro need extrapolation to match the in vivo situation.

Effective risk management requires quantitative risk assessment and thus information about allergen potency, i.e. EC3 values from a LLNA. Other test alternatives to the LLNA are the Magnusson and Kligman maximisation test and the occluded patch test of Buehler, which use guinea pigs as test system $[154,155]$. These tests predict skinsensitising substances (EU-label R43) with $85-90 \%$ accuracy, although the LLNA is the only test formally validated. Decisions on the classification of allergens follow a weight of evidence approach. They are primarily based on the in vivo test results, but include the chemical structure as well as clinical data in order to reduce the number of false positives and false negatives [156]. This strategy has been successful in identifying major skin sensitisers. However, it fails to spot potential allergens that fail to generate a test response of sufficient magnitude.

\section{Skin sensitisers: chemical reactivity as a tool for hazard} and potency prediction

Chemical reactivity has been seen as a key parameter for allergenic sensitisation since it was first discussed in the 1930s [157]. 'Quantitative Structure Activities Relationships' (QSAR) can be used to evaluate the sensitising potential of allergens based on physicochemical parameters like chemical and thermodynamic constants, reactivity and the partition coefficient. Predictions tend to be accurate for molecules that share the same reaction mechanism. However, QSAR can be difficult for substance classes that have more than one option on how to react with the reaction partner, e.g. aldehydes [158, 159]. Together with nucleophilic proteins saturated aldehydes form Schiff bases while $\alpha, \beta$-unsaturated aldehydes also have the option of undergoing a Michael addition reaction [160]. In the latter case QSAR-predicted EC3 values can differ significantly from the ones obtained in vivo [161].

Peptide assays can be used to look into the reactivity of potential allergens in more detail. The reactivity of potential chemical allergens was compared using glutathione and synthetic peptides containing lysine, histidine or cysteine [162]. The assay showed the highest sensitivity with cysteine as functional group, while histidine was the least sensitive. Notably the assay identified some substances of low and moderate protein reactivity, which are known to be negative in the LLNA, i.e. 2-hydroxypropyl methacrylate, 1-bromobutane, 2-acetylcyclohexanone, propylparaben or vanillin. However, the assay inherently failed to detect prohaptens such as aminophenol or 3,4,dihydrocoumarin. While most skin sensitisers reacted with cysteine, some were found to react with lysine and others with amino groups in general. Substances binding to any polypeptide correlated well with known potent sensitisers. The best results were achieved with a prediction system based on reactivity thresholds towards the functional groups of cysteine and lysine [163].

\section{In vitro identification of allergens}

The migration of LCs is a key process during contact sensitisation and can be used for alternative testing strategies. LC migration in human skin biopsies has been successfully used to distinguish allergens from irritants and to assess allergen potency [164, 165]. However, as an ex vivo method it is laborious and unsuitable for high throughput screenings because of the limited availability of suitable human skin. 
One alternative is the DC culture. Peripheral blood monocytes can be differentiated to monocyte-derived dendritic cells (MoDCs) by adding granulocyte macrophage colony-stimulating factor and IL-4 to the culture medium [166]. Effects of allergens added to the maturing MoDCs can be followed by measuring the expression levels of the dendritic cell maturation marker CD83, the co-stimulatory molecule CD86 and the chemokine CXCL8 [167]. Exposure to allergens like $\mathrm{NiSO}_{4}, \mathrm{CrCl}_{3}, \mathrm{CuSO}_{4}$ and DNCB lead to elevated levels for all three markers. The expression of CXCL8 was increased by seven out of eight allergens, but was not affected by the addition of irritants, i.e. DMSO, SDS or 1-propanol. This shows that the system can be used to distinguish allergens from irritants. Other increased markers were identified recently and include IL8, TRIM16 and AKR1C2 [168]. Furthermore, systems based on DCs are a suitable tool to identify potential contact allergens. Transcriptomic profiling of $\mathrm{CD} 34^{+}$DCs following allergen exposure resulted in the identification of 13 genes, most prominently CREM and CCR. Within the initial set of 21 substances this marker set detected skin sensitisers with a concordance of $89 \%$ and a specificity of 97\% [169]. Intriguingly gene expression levels seem partially to correlate with sensitising potency, thus allowing a preliminary classification of the test results [170]. Another study recently identified a biomarker signature of 200 genes in MUTZ-3 cells, following a 24 h-treatment with 20 sensitisers and 20 non-sensitisers respectively [171]. In a comparative study MoDCs and DCs from CD34 ${ }^{+}$precursors recognised 76 and $67 \%$ of all tested contact allergens. In addition, using the leukaemic THP-1 cell line, the histiocytic lymphoma U-937 cell line and the acute myeloid leukaemia MUTZ-3 cell line, 70, 83 and 100\% of contact allergens, respectively, could be identified (T.R., unpublished). Two of these test systems are currently prevalidated for regulatory purposes, namely the myeloid 'U-937 Skin Sensitisation Test' (MUSST) [172, 173] and the THP-1 based 'human Cell Line Activation Test' (hCLAT) [174, 175]. Both test systems use the expression of CD86 as readout for dendritic cell activation, supplemented by the adhesion molecule CD54 for hCLAT [176]. Comparative studies recently highlighted the use of the latter system in regard to surfactants, a substance group for which the LLNA is known to report false positives [177].

The $\mathrm{T}$ cell polarising potential of contact allergens was investigated using oxazolone, $\mathrm{DNCB}$ and $\mathrm{NiSO}_{4}$. Stimulation of MoDC cultures with the latter induced high levels of the Th1 polarising cytokines TNF- $\alpha$ and CXCL10 [167]. Analysis of the IL-12p70 (Th1)/IL-10 (Th2) ratio showed no effect for oxazolone, whereas DNCB enhanced a Th1 response. Notably $\mathrm{NiSO}_{4}$ induced a $\mathrm{Th} 2$ response, which is the exception for contact allergens but had been suggested earlier by clinical studies [178]. As contact allergen nickel has the ability to activate the NF- $\kappa \mathrm{B}$ pathway, which usually leads to the release of inflammatory cytokines by DCs [179]. Altogether it appears that the activation of DCs is influenced by intrinsic properties of the respective allergens. This is supported by the observation that contact and respiratory allergens tend to cause Th1- or Th2-associated diseases respectively [167, 178].

While DCs are crucial during initial sensitisation any subsequent allergic reaction is caused as a consequence of effective $\mathrm{T}$ cell stimulation following allergenic re-exposure. Complex as it might be, stimulation of naïve $\mathrm{T}$ cells is thus an effective target for any in vitro testing strategy. Naïve T cells can either polarise to cytotoxic T cells $\left(\mathrm{CD}^{+}\right.$ $\left.\mathrm{CD}^{+}\right)$or Th cells $\left(\mathrm{CD}^{+} \mathrm{CD}^{+}\right)$. The latter further specialise to Th1, Th2 and IL-17 releasing Th cells (Th17), or to regulatory $\mathrm{T}$ cells. Two further $\mathrm{T}$ cell populations, Th22 and Th9, were described recently, and their role in hypersensitivity remains to be determined [180-183]. Matters are further complicated by the fact that, to an as yet undefined extent, contact hypersensitivity is regulated by the balance of inflammatory (Th) versus inhibitory $\left(\mathrm{T}_{\text {reg }}\right)$ cells present at the site of antigen exposure. This balance is in turn regulated by the expression of $\mathrm{P}$ - and E-selectin ligands and chemokine receptors on $\mathrm{T}$ cells proliferating in the lymph nodes draining that site [Fuhlbrigge unpublished, 184, 185]. Current assays thus mainly focus on the priming of CD45RA $+\mathrm{T}$ cells, using cell proliferation and production of IFN- $\gamma$ or IL-5 as readouts [for a recent review please see ref. 186]. Depletion of regulatory $\mathrm{CD} 25^{+}$- or $\mathrm{CD}^{+}{ }^{-} \mathrm{T}$ cells in vivo increases the number of IFN- $\gamma$-producing $\mathrm{T}$ cells during sensitisation. Likewise the sensitivity of the corresponding in vitro assays can be increased by using systems depleted of $\mathrm{CD}_{2} 5^{+} \mathrm{T}$ cells [187, 188].

Another potential target for in vitro testing is Th cells. Promotion of Th17 involves several cytokines (IL-6, IL-1 $\beta$, TGF- $\beta$ and IL-23) and can be driven by LCs following the stimulation of TLR 2 [189]. The involvement of TLR 2 links Th17 to dermal inflammation. Nevertheless Th17 cells seem likewise to be involved in contact allergy as IL-17 was shown to promote type-IV hypersensitivity to DNFB [190, 191]. Furthermore, $\mathrm{NiSO}_{4}$ stimulates LCs to release IL-6, IL-1 $\beta$ and IL-23 (M.P., unpublished), and IL-17 was previously found in nickel-specific T cells [192]. Allergens like cinnamal and DNCB fail to induce a Th17 phenotype in naïve $\mathrm{T}$ cells, suggesting a different mechanism (M.P., unpublished). Contact hypersensitivity thus involves Th cell subpopulations, other than just Th1, which could be considered for the design of future in vitro assays.

Other cells like NK cells are also implicated to be effector cells for allergic inflammatory responses of the skin [193, 194]. In T/B cell-deficient mice, NK cells can initiate allergic responses to DNFB, oxazolone and picryl 
chloride. These responses are contact allergen-specific and can be recalled weeks after sensitisation. In the absence of $\mathrm{T}$ and $\mathrm{B}$ cells contact allergens thus induce memory-like responses that depend on liver NK cells expressing the chemokine receptor CXCR6. Further on NK cells also infiltrate the skin of $w t$ mice $[193,194]$ and humans during allergic contact dermatitis [195]. In human contact dermatitis they seem to amplify the allergic reaction.

\section{Dose response and threshold issues in chemically induced skin sensitisation and its implications in regulatory toxicology}

\section{Assessing contact allergen potency and thresholds in the local lymph node assay}

Sensitisation to an allergen depends on its potency and allergenic exposure in terms of frequency, duration and site. The LLNA assesses sensitisation potency and thus allows the identification and comparison of potential allergens (Fig. 3). This was further demonstrated by ranking the sensitising potential of rubber chemicals [196]. In this study an EC3 value was estimated from a dose response curve by fitting non-linear regression models. Uncertainty was limited to a $90 \%$ confidence interval by parametric bootstrapping. The resulting 5th percentile of the EC3 value from the bootstrapping method represents the dose where an allergic reaction will occur with a 5\% probability and is similar to the benchmark dose limit (BMDL). Ultimately the data of LLNA allow to set exposure thresholds, defining a sensitising dose per unit area [197].

Generally LLNA thresholds correlate well with human thresholds. A critical question is whether prolonged exposure to an allergen below its threshold can cause sensitisation. Therefore mice were subjected to an extended LLNA, exposing them to 2,4-dinitro-1-chlorobenzene, benzocaine and tetramethylthiuram disulfide below the corresponding EC3 values. After 56 days the lymph nodes showed no increased cell proliferation [198]. Similar negative results were seen with paraformaldehyde and hexamethylenetetramine. However, formaldehyde, 2-chloro$\mathrm{N}$ - (hydroxymethyl)acetamide and quaternium-15 showed positive results in an extended LLNA [199]. The underlying mechanisms leading to sensitisation at exposure levels below the LLNA thresholds are unclear. Nevertheless the results show that the use of EC3 values as thresholds for no risk of sensitisation has to be evaluated carefully.

\section{The LLNA as a tool to assess respiratory allergens}

The LLNA has been proven to be a reliable test for the identification of dermal sensitisers. In addition it shows positive test results for almost all known respiratory sensitisers [200]. This implies firstly that respiratory allergens could induce allergies following dermal exposure and secondly, that dermal tests can be used to identify potential respiratory allergens.

This was tested by adapting the dermal LLNA to fit respiratory exposure. BALB/c mice were exposed head/ nose-only to various allergens (respiratory and dermal) during 3 consecutive days. Allergen exposure was at a constant concentration for $45,90,180$ or $360 \mathrm{~min} /$ day. Three days after the last exposure cell proliferation was determined in the mandibular lymph nodes, which drain the respiratory tract [201]. The respiratory allergens trimellitic anhydride (TMA), phthalic anhydride (PA), hexamethylene diisocyanate (HDI), toluene diisocyanate (TDI) and isophorone diisocyanate (IPDI) showed a more than three-fold induction of $\mathrm{T}$ cell proliferation, as did the contact allergens DNCB and oxazolone. For TDI, HDI, IPDI and oxazolone proliferation values were even higher in the auricular lymph nodes. It is assumed that these substances have an increased dermal absorption due to their lipophilicity. Other substances, like the dermal allergen formaldehyde, the irritant methylsalicylate and the unclassified trimeric IPDI, were found to be negative in the respiratory LLNA. Altogether the contact allergens turned out to be as potent as the respiratory allergens in the respiratory LLNA, although the resulting potency ranking differed from that of a dermal LLNA [201]. Therefore all substances testing positively in the LLNA should be considered to be a potential respiratory allergen as well as a dermal allergen.

Risk assessment and risk management for skin-sensitising chemicals

Quantitative risk assessment for fragrance compounds Fragrances are among the most frequent sensitisers in cosmetic products. The corresponding risk assessments are based on the no-observed-effect-level (NOAEL) and a qualitative assessment of exposure (i.e. the NOAEL for substances with non-skin contact and NOAEL/ 10 for substances with skin contact). This categorisation into just two product groups prevents any further distinction of possible exposure or differences in the experienced dose due to e.g. different applications. Hence a recent approach suggested the use of a quantitative risk assessment (QRA) for fragrance compounds [202, 203]. The method is based on the following four steps: (1) hazard identification, (2) dose/response relationship, (3) exposure assessment and (4) risk characterisation. Hazard identification reviews experimental data and clinical data to identify the potential hazard of a fragrance substance to cause sensitisation. The dose/response relationship then 
uses a weight of evidence approach to determine the "no expected sensitisation induction level' (NESIL) and derives a sensitisation assessment factor (SAF) based on the most likely scenario of exposure. The latter will include (1) the inter-individual variability (i.e. age, gender, genetics), (2) matrix effects from varying product formulations (i.e. irritant or skin damaging) and (3) differences of the exposure scenario in the experimental setup (i.e. application on sensitive skin areas). Each parameter is factored between 1 and 10, the SAF being the product of all three factors. Division of the NESIL by the SAF aims to provide an 'acceptable exposure level' (AEL). The AEL is finally compared to the expected consumer exposure level (CEL), based on estimates about the amount of product used, the frequency of application and the duration of use. For safe products the CEL should be smaller than, or equal to, the AEL [203]. The approach was formally implemented by the 'International Fragrance Association's (IFRA) code of practice in 2006 and to date more than 80 standards have been evaluated using QRA. However, QRA remains a predictive model and has not been adequately assessed against clinical or epidemiological data.

Risk management for contact allergens In the recent years Europe has implemented a whole set of regulations aimed at reducing the exposure of the workforce and consumers to contact allergens. Examples are the 'Nickel Directive', limiting the release of nickel in contact with

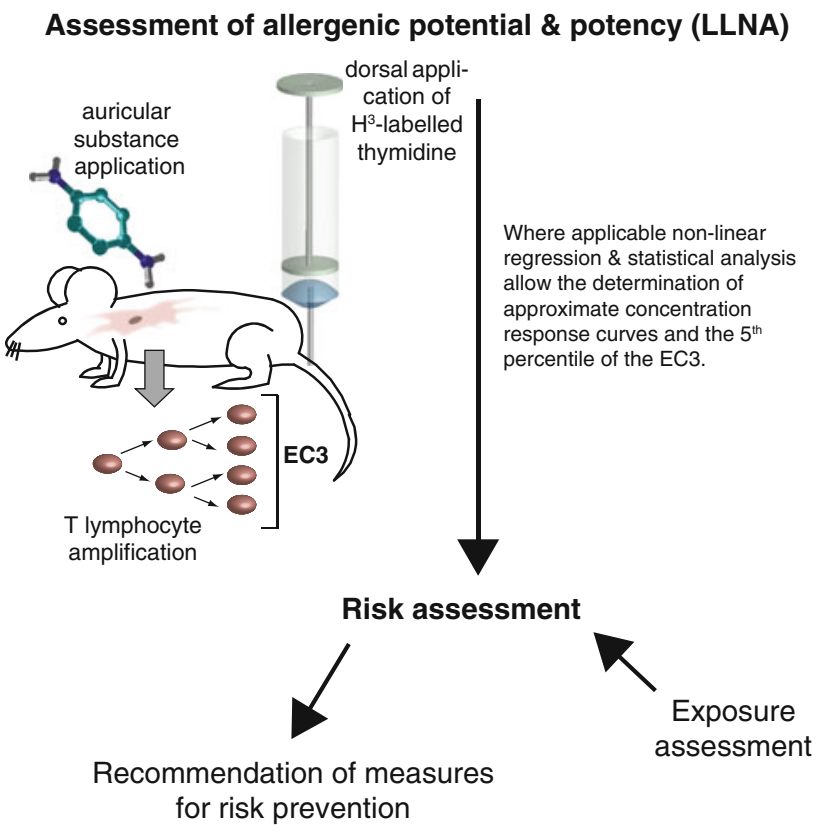

Fig. 3 Use of the LLNA for the regulatory risk assessment of potential allergens. The 5th percentile of the EC3 is similar to a probabilistic BMDL. Alternatively the respective data might be used to estimate a threshold concentration, similar to a 'lowest adverse effect level' (LOAEL) skin to $0.5 \mu \mathrm{g} /\left(\mathrm{cm}^{2}\right.$ per week) [10], and the 'Chromium Directive', limiting $\mathrm{Cr}^{\mathrm{VI}}$ to $2 \mathrm{ppm}$ in the total dry weight of cement [29]. The directive on detergents requires the listing of preservatives and listed fragrances if their content in detergents and similar household products exceeds $100 \mathrm{ppm}$ [204]. Detergents are thus treated as rinse-off cosmetics. Furthermore, details of the product formulation have to be released when necessary, i.e. to investigate adverse reactions. As a result of this regulation the preservative MDGN was banned from all cosmetic products in 2008. Prior to the ban cosmetic products were allowed to contain up to $0.1 \% \mathrm{MDGN}$, a level that was found to cause elicitation. A reassessment of MDGN failed to establish a safe level of use and thus recommended the ban of the substance [205].

A decision on the ban/restriction of PPD and other ingredients of hair dyes is still pending. The median prevalence of contact dermatitis against PPD in Europe is 2-6\% [32]. The EU Commission's Scientific Committee on Consumer Products (SCCP) assessed the skin sensitising properties of 48 hair dye substances in 2006, finding 27 of them to be skin sensitising according to the European classification R43. In conclusion the SCCP stated that products containing theses substances might not be safe for consumer use [206]. Industry has suggested to introduce sensitivity self-testing as a regulatory requirement. However, this approach is problematic due to the possibility of false-negative results, the induction of skin sensitisation and ethical reasons [207]. Further, on application of hair dyes to the skin, the product is being used for in vivo diagnostic purposes and is thus outwith the legal framework for cosmetics. Discussions continue on the safety of PPD and similar ingredients in hair dyes

Likewise further regulation is needed for fragrance substances. The labelling of fragrances was first addressed in the 7th amendment of the first European cosmetics directive [208] and subsequently included in the new European cosmetics regulation [27]. As a consequence, the industry introduced the concept of the aforementioned QRA for the evaluation of fragrance substances. Undoubtedly this will be a useful approach for new substances. However, concerns remain that QRA fails to protect previously sensitised consumers and that aggregate exposures through multiple products are not considered in the basic form of the QRA. Therefore epidemiological and clinical data continue to represent a critical decision point in risk assessment and risk management [209].

\section{Conclusion}

Skin sensitisation and subsequent contact dermatitis is a significant problem for consumers and workers. It is 
clear that the immune response to contact allergens is more complex than previously thought and described. Different allergens elicit different immune responses and mechanisms for the activation of allergens can differ substantially. Research efforts are underway to elucidate the complex biochemistry and molecular biology underlying contact dermatitis. Several in vivo systems have been established that are able to identify potential allergens reliably and to assess their potency. At the same time in vitro tests are developed because of public demand to replace in vivo tests, animal welfare and costs. However, their regulatory acceptance will depend on a thorough validation, not only against other methods (internal validation) but also against human observational data from clinical epidemiological surveillance systems (external validation). Such validation is the indispensible gold standard for any predictive safety assessment. Legislation has to focus on the protection of consumers and workers against potential allergens, and it is adapted continuously as our understanding of allergic contact dermatitis progresses. In this context clinical data and the epicutaneous patch test as published by Jadassohn more than 100 years ago [210] are invaluable as they highlight substances and problems missed by other approaches.

Acknowledgment We would like to thank all the contributors that helped to make the 'Workshop on Contact Dermatitis' (BfR, Berlin, Germany, October 27-28, 2008) a success.

Open Access This article is distributed under the terms of the Creative Commons Attribution Noncommercial License which permits any noncommercial use, distribution, and reproduction in any medium, provided the original author(s) and source are credited.

\section{References}

1. Nguyen SH, Dang TP, MacPherson C, Maibach H, Maibach HI (2008) Prevalence of patch test results from 1970 to 2002 in a multi-centre population in North America (NACDG). Contact Dermat 58(2):101-106

2. Kohl L, Blondeel A, Song M (2002) Allergic contact dermatitis from cosmetics. Retrospective analysis of 819 patch-tested patients. Dermatology 204(4):334-337

3. Lunder T, Kansky A (2000) Increase in contact allergy to fragrances: patch-test results 1989-1998. Contact Dermat 43(2):107109

4. Thyssen JP, Linneberg A, Menné T, Johansen JD (2007) The epidemiology of contact allergy in the general populationprevalence and main findings. Contact Dermat 57(5):287-299

5. Mortz CG, Lauritsen JM, Bindslev-Jensen C, Andersen KE (2002) Contact allergy and allergic contact dermatitis in adolescents: prevalence measures and associations: the Odense adolescence cohort study on atopic diseases and dermatitis (TOACS). Acta Derm Venereol 82(5):352-358

6. Diepgen TL (2003) Occupational skin-disease data in Europe. Int Arch Occup Environ Health 76(5):331-338
7. Diepgen TL, Coenraads PJ (1999) The epidemiology of occupational contact dermatitis. Int Arch Occup Environ Health 72(8):496-506

8. Diepgen TL, Schmidt A (2002) Are the incidence and prevalence of occupational skin diseases underestimated? Arbeitsmed Sozialmed Umweltmed 37(10):477-480

9. Dickel H, Kuss O, Blesius CR, Schmidt A, Diepgen TL (2001) Occupational skin diseases in Northern Bavaria between 1990 and 1999: a population-based study. Br J Dermatol 145(3):453462

10. European Parliament and Council Directive 94/27/EC (1994). Off J Eur Union L-188:1-2

11. Schnuch A, Uter W (2003) Decrease in nickel allergy in Germany and regulatory interventions. Contact Dermat 49(2):107-108

12. Lindberg M, Edman B, Fischer T, Stenberg B (2007) Time trends in Swedish patch test data from 1992 to 2000. A multicentre study based on age- and sex-adjusted results of the Swedish standard series. Contact Dermat 56(4):205-210

13. Jensen CS, Lisby S, Baadsgaard O, Vølund A, Menné T (2002) Decrease in nickel sensitization in a Danish schoolgirl population with ears pierced after implementation of a nickel-exposure regulation. Br J Dermatol 146(4):636-642

14. Schnuch A, Wolter J, Geier J, Uter W (2011) Nickel allergy is still frequent in young German females-probably because of insufficient protection from nickel-releasing objects. Contact Dermat 64(3):142-150

15. Lidén C, Skare L, Nise G, Vahter M (2008) Deposition of nickel, chromium, and cobalt on the skin in some occupationsassessment by acid wipe sampling. Contact Dermat 58(6):347354

16. Thyssen JP, Johansen JD, Zachariae C, Menné T (2008) The outcome of dimethylglyoxime testing in a sample of cell phones in Denmark. Contact Dermat 59(1):38-42

17. Thyssen JP, Uter W, Schnuch A, Linneberg A, Johansen JD (2007) 10-year prevalence of contact allergy in the general population in Denmark estimated through the CE-DUR method. Contact Dermat 57(4):265-272

18. Krautheim A, Uter W, Frosch P, Schnuch A, Geier J (2010) Patch testing with fragrance mix II: results of the IVDK 2005-2008. Contact Dermat 63(5):262-269

19. Thyssen JP, Carlsen BC, Menné T, Johansen JD (2008) Trends of contact allergy to fragrance mix I and Myroxylon pereirae among Danish eczema patients tested between 1985 and 2007. Contact Dermat 59(4):238-244

20. Uter W, Geier J, Frosch P, Schnuch A (2010) Contact allergy to fragrances: current patch test results (2005-2008) from the Information Network of Departments of Dermatology. Contact Dermat 63(5):254-261

21. Uter W, Schmidt E, Geier J, Lessmann H, Schnuch A, Frosch P (2010) Contact allergy to essential oils: current patch test results (2000-2008) from the Information Network of Departments of Dermatology (IVDK). Contact Dermat 63(5):277-283

22. Christensson JB, Matura M, Gruvberger B, Bruze M, Karlberg AT (2010) Linalool—a significant contact sensitizer after air exposure. Contact Dermat 62(1):32-41

23. Matura M, Goossens A, Bordalo O, Garcia-Bravo B, Magnusson K, Wrangsjö K, Karlberg AT (2002) Oxidized citrus oil (R-limonene): a frequent skin sensitizer in Europe. J Am Acad Dermatol 47(5):709-714

24. Matura M, Sköld M, Börje A, Andersen KE, Bruze M, Frosch P, Goossens A, Johansen JD, Svedman C, White IR, Karlberg AT (2005) Selected oxidized fragrance terpenes are common contact allergens. Contact Dermat 52(6):320-328

25. Braendstrup P, Johansen JD (2008) Hydroxyisohexyl 3-cyclohexene carboxaldehyde (Lyral) is still a frequent allergen. Contact Dermat 59(3):187-188 
26. Uter W, Geier J, Schnuch A, Frosch PJ (2007) Patch test results with patients' own perfumes, deodorants and shaving lotions: results of the IVDK 1998-2002. J Eur Acad Dermatol Venereol 21(3):374-379

27. European Parliament and Council Regulation (EC) No. 1223/2009 (2009). Off J Eur Union L-342:59-209

28. Irvine C, Pugh CE, Hansen EJ, Rycroft RJG (1994) Cement dermatitis in underground workers during construction of the Channel Tunnel. Occup Med 44(1):17-23

29. European Parliament and Council Directive 2003/53/EC (2003). Off J Eur Union L-178:24-27

30. Geier J, Krautheim A, Uter W, Lessmann H, Schnuch A (2011) Occupational contact allergy in the building trade in Germany: influence of preventive measures and changing exposure. Int Arch Occup Environ Health 84(4):403-411

31. Geier J, Schnuch A, Frosch PJ (2000) Contact allergy to dichromate in women. Dermatologie in Beruf und Umwelt 48(1):4-10

32. Thyssen JP, White JML (2008) Epidemiological data on consumer allergy to $p$-phenylenediamine. Contact Dermat 59(6): 327-343

33. Wöhrl S, Hemmer W, Focke M, Götz M, Jarisch R (2001) Hypopigmentation after non-permanent henna tattoo. J Eur Acad Dermatol Venereol 15(5):470-472

34. Ho SG, Basketter DA, Jefferies D, Rycroft RJ, White IR, McFadden JP (2005) Analysis of para-phenylenediamine allergic patients in relation to strength of patch test reaction. $\mathrm{Br} \mathrm{J}$ Dermatol 153(2):364-367

35. Søsted H, Johansen JD, Andersen KE, Menné T (2006) Severe allergic hair dye reactions in 8 children. Contact Dermat 54(2):87-91

36. Schnuch A, Lessmann H, Frosch PJ, Uter W (2008) paraPhenylenediamine: the profile of an important allergen. Results of the IVDK. Br J Dermatol 159(2):379-386

37. Lerbaek A, Kyvik KO, Ravn H, Menné T, Agner T (2007) Incidence of hand eczema in a population-based twin cohort: genetic and environmental risk factors. Br J Dermatol 157(3): 552-557

38. de Jongh CM, Khrenova L, Verberk MM, Calkoen F, van Dijk FJH, Voss H, John SM, Kezic S (2008) Loss-of-function polymorphisms in the filaggrin gene are associated with an increased susceptibility to chronic irritant contact dermatitis: a case-control study. Br J Dermatol 159(3):621-627

39. Lerbaek A, Bisgaard H, Agner T, Ohm Kyvik K, Palmer CNA, Menné T (2007) Filaggrin null alleles are not associated with hand eczema or contact allergy. Br J Dermatol 157(6):1199-1204

40. Allen MH, Wakelin SH, Holloway D, Lisby S, Baadsgaard O, Barker JNWN, McFadden JP (2000) Association of TNF $\alpha$ gene polymorphism at position -308 with susceptibility to irritant contact dermatitis. Immunogenetics 51(3):201-205

41. Schnuch A, Carlsen BC (2011) Genetics and individual predispositions in contact dermatitis. In: Johansen JD, Frosch PJ, Lepoittevin JP (eds) Contact dermatitis, 5th edn. Springer, Berlin, pp 13-42

42. Uter W, Geier J, Pfahlberg A, Effendy I (2002) The spectrum of contact allergy in elderly patients with and without lower leg dermatitis. Dermatology 204(4):266-272

43. de Pádua MCA, Schnuch A, Lessmann H, Geier J, Pfahlberg A, Uter W (2005) Contact allergy to neomycin sulfate: results of a multifactorial analysis. Pharmacoepidemiol Drug Saf 14(10): 725-733

44. Brasch J, Schnuch A, Uter W (2006) Strong allergic patch test reactions may indicate a general disposition for contact allergy. Allergy 61(3):364-369

45. Schnuch A, Brasch J, Lessmann H, Geier J, Uter W (2007) A further characteristic of susceptibility to contact allergy: sensitization to a weak contact allergen is associated with polysensitization. Results of the IVDK. Contact Dermat 56(6):331-337

46. Schnuch A, Uter W, Reich K (2006) Allergic contact dermatitis and atopic eczema. In: Ring J, Przybilla B, Ruzicka T (eds) Handbook of atopic eczema. Springer, Berlin, pp 178-201

47. Schnuch A, Westphal G, Mossner R, Uter W, Reich K (2011) Genetic factors in contact allergy-review and future goals. Contact Dermat 64(1):2-23

48. Schnuch A, Westphal GA, Müller MM, Schulz TG, Geier J, Brasch J, Merk HF, Kawakubo Y, Richter G, Koch P, Fuchs T, Gutgesell T, Reich K, Gebhardt M, Becker D, Grabbe J, Szliska C, Aberer W, Hallier E (1998) Genotype and phenotype of $N$ acetyltransferase 2 (NAT2) polymorphism in patients with contact allergy. Contact Dermat 38(4):209-211

49. Westphal GA, Reich K, Schulz TG, Neumann C, Hallier E, Schnuch A (2000) $N$-acetyltransferase 1 and 2 polymorphisms in para-substituted arylamine-induced contact allergy. Br J Dermatol 142(6):1121-1127

50. Blömeke B, Brans R, Coenraads PJ, Dickel H, Bruckner T, Hein DW, Heesen M, Merk HF, Kawakubo Y (2009) para-Phenylenediamine and allergic sensitization: risk modification by $\mathrm{N}$-acetyltransferase 1 and 2 genotypes. Br J Dermatol 161(5): 1130-1135

51. Westphal GA, Schnuch A, Schulz TG, Reich K, Aberer W, Brasch J, Koch P, Wessbecher R, Szliska C, Bauer A, Hallier E (2000) Homozygous gene deletions of the glutathione S-transferases M1 and T1 are associated with thimerosal sensitization. Int Arch Occup Environ Health 73(6):384-388

52. Wang BJ, Shiao JS, Chen CJ, Lee YC, Guo YL (2007) Tumour necrotizing factor- $\alpha$ promoter and GST-T1 genotype predict skin allergy to chromate in cement workers in Taiwan. Contact Dermat 57(5):309-315

53. Westphal GA, Schnuch A, Moessner R, König IR, Kränke B, Hallier E, Ziegler A, Reich K (2003) Cytokine gene polymorphisms in allergic contact dermatitis. Contact Dermat 48(2):9398

54. Reich K, Westphal G, König IR, Mössner R, Krüger U, Ziegler A, Neumann C, Schnuch A (2003) Association of allergic contact dermatitis with a promoter polymorphism in the IL16 gene. J Allergy Clin Immunol 112(6):1191-1194

55. Nacak M, Erbagci Z, Buyukafsar K, Yurtsever AS, Tiftik RN (2007) Association of angiotensin-converting enzyme gene insertion/deletion polymorphism with allergic contact dermatitis. Basic Clin Pharmacol Toxicol 101(2):101-103

56. Kwangsukstith C, Maibach HI (1995) Effect of age and sex on the induction and elicitation of allergic contact dermatitis. Contact Dermat 33(5):289-298

57. Hermann-Kunz E (2000) Allergische Krankheiten in Deutschland Ergebnisse einer repräsentativen Studie. Bundesgesundheitsbl Gesundheitsforsch Gesundheitssch 43(6):400-406

58. Uter W, Pfahlberg A, Gefeller O, Geier J, Schnuch A (2003) Risk factors for contact allergy to nickel-results of a multifactorial analysis. Contact Dermat 48(1):33-38

59. Rees JL, Friedmann PS, Matthews JN (1989) Sex differences in susceptibility to development of contact hypersensitivity to dinitrochlorobenzene (DNCB). Br J Dermatol 120(3):371-374

60. Berardesca E, Gabba P, Farinelli N, Borroni G, Rabbiosi G (1989) Skin extensibility time in women. Changes in relation to sex hormones. Acta Derm Venereol 69(5):431-433

61. Brasch J, Geier J (1997) Patch test results in schoolchildren. Results from the Information Network of Departments of Dermatology (IVDK) and the German Contact Dermatitis Research Group (DKG). Contact Dermat 37(6):286-293

62. Goh CL (1986) Prevalence of contact allergy by sex, race and age. Contact Dermat 14(4):237-240 
63. Wedig JH, Maibach HI (1981) Percutaneous penetration of dipyrithione in man: effect of skin color (race). J Am Acad Dermatol 5(4):433-438

64. Reed JT, Ghadially R, Elias PM (1995) Skin type, but neither race nor gender, influence epidermal permeability barrier function. Arch Dermatol 131(10):1134-1138

65. Lammintausta K, Kalimo K, Aantaa S (1982) Course of hand dermatitis in hospital workers. Contact Dermat 8(5):327-332

66. Dickel H, Bruckner TM, Schmidt A, Diepgen TL (2003) Impact of atopic skin diathesis on occupational skin disease incidence in a working population. J Invest Dermatol 121(1):37-40

67. Funke U, Fartasch M, Diepgen TL (2001) Incidence of workrelated hand eczema during apprenticeship: first results of a prospective cohort study in the car industry. Contact Dermat 44(3):166-172

68. Thyssen JP, Johansen JD, Menné T (2007) Contact allergy epidemics and their controls. Contact Dermat 56(4):185-195

69. Johansen JD, Veien N, Laurberg G, Avnstorp C, Kaaber K, Andersen KE, Paulsen E, Sommerlund M, Thormann J, Nielsen $\mathrm{NH}$, Vissing S, Kristensen O, Kristensen B, Agner T, Menne T (2008) Decreasing trends in methyldibromo glutaronitrile contact allergy - following regulatory intervention. Contact Dermat 59(1):48-51

70. Uter W, Geier J, Lessmann H, Schnuch A (2006) Is contact allergy to glyceryl monothioglycolate still a problem in Germany? Contact Dermat 55(1):54-56

71. Dickel H, Kuss O, Schmidt A, Diepgen TL (2002) Impact of preventive strategies on trend of occupational skin disease in hairdressers: population based register study. $\mathrm{Br}$ Med $\mathrm{J}$ 324(7351):1422-1423

72. Kutting B, Drexler H (2008) The three-step programme of skin protection-a useful instrument of primary prevention or more effective in secondary prevention? Dt Mediz Wochenschr 133(5):201-205

73. Agner T, Held E (2002) Skin protection programmes. Contact Dermat 47(5):253-256

74. Gober MD, Gaspari AA (2008) Allergic contact dermatitis. Curr Dir Autoimmun 10:1-26

75. Kim BS, Miyagawa F, Cho YH, Bennett CL, Clausen BE, Katz SI (2009) Keratinocytes function as accessory cells for presentation of endogenous antigen expressed in the epidermis. J Invest Dermatol 129(12):2805-2817

76. Trautmann A, Akdis M, Schmid-Grendelmeier P, Disch R, Brocker EB, Blaser K, Akdis CA (2001) Targeting keratinocyte apoptosis in the treatment of atopic dermatitis and allergic contact dermatitis. J Allergy Clin Immunol 108(5):839-846

77. Ale IS, Maibach HI (2008) Mechanisms in irritant and allergic contact dermatitis. In: Zhai H, Wilhem K-P, Maibach HI (eds) Dermatotoxicology, 7th edn. CRC Press, London, pp 159-167

78. Martin SF, Pichler WJ (2007) Chemical-induced contact hypersensitivity in the mouse model. In: Drug hypersensitivity. Karger, Basel, pp 34-46

79. Dudda JC, Simon JC, Martin S (2004) Dendritic cell immunization route determines $\mathrm{CD} 8+\mathrm{T}$ cell trafficking to inflamed skin: role for tissue microenvironment and dendritic cells in establishment of T cell-homing subsets. J Immunol 172(2):857863

80. Dudda JC, Lembo A, Bachtanian E, Huehn J, Siewert C, Hamann A, Kremmer E, Forster R, Martin SF (2005) Dendritic cells govern induction and reprogramming of polarized tissueselective homing receptor patterns of T cells: important roles for soluble factors and tissue microenvironments. Eur J Immunol 35(4):1056-1065

81. Edele F, Molenaar R, Gütle D, Dudda JC, Jakob T, Homey B, Mebius R, Hornef M, Martin SF (2008) Cutting edge: instructive role of peripheral tissue cells in the imprinting of $\mathrm{T}$ cell homing receptor patterns. J Immunol 181(6):3745-3749

82. Cavani A, Nasorri F, Ottaviani C, Sebastiani S, De Pita O, Girolomoni G (2003) Human CD25 ${ }^{+}$regulatory T cells maintain immune tolerance to nickel in healthy, nonallergic individuals. J Immunol 171(11):5760-5768

83. Reduta T, Stasiak-Barmuta A, Laudanska H (2011) $\mathrm{CD} 4{ }^{+} \mathrm{CD} 25^{+}$and $\mathrm{CD} 4{ }^{+} \mathrm{CD} 25^{\text {high }}$ regulatory $\mathrm{T}$ cells in disseminated and localized forms of allergic contact dermatitis: relation to specific cytokines. Folia Histochemica et Cytobiologica 49(2):255-262

84. Sakaguchi S, Sakaguchi N, Asano M, Itoh M, Toda M (1995) Immunologic self-tolerance maintained by activated $\mathrm{T}$ cells expressing IL-2 receptor alpha-chains (CD25). Breakdown of a single mechanism of self-tolerance causes various autoimmune diseases. J Immunol 155(3):1151-1164

85. Sakaguchi S, Toda M, Asano M, Itoh M, Morse SS, Sakaguchi N (1996) T cell-mediated maintenance of natural self-tolerance: its breakdown as a possible cause of various autoimmune diseases. J Autoimmun 9(2):211-220

86. Honda T, Miyachi Y, Kabashima K (2011) Regulatory T cells in cutaneous immune responses. J Dermatol Sci 63(2):75-82

87. Vocanson M, Hennino A, Rozieres A, Poyet G, Nicolas JF (2009) Effector and regulatory mechanisms in allergic contact dermatitis. Allergy 64(12):1699-1714

88. Yoshiki R, Kabashima K, Sugita K, Atarashi K, Shimauchi T, Tokura Y (2009) IL-10-producing Langerhans cells and regulatory $\mathrm{T}$ cells are responsible for depressed contact hypersensitivity in grafted skin. J Invest Dermatol 129(3):705-713

89. Ring S, Karakhanova S, Johnson T, Enk AH, Mahnke K (2010) Gap junctions between regulatory $\mathrm{T}$ cells and dendritic cells prevent sensitization of CD8(+) T cells. J Allergy Clin Immunol 125(1):237-246

90. Vocanson M, Rozieres A, Hennino A, Poyet G, Gaillard V, Renaudineau S, Achachi A, Benetiere J, Kaiserlian D, Dubois B, Nicolas JF (2010) Inducible costimulator (ICOS) is a marker for highly suppressive antigen-specific $\mathrm{T}$ cells sharing features of TH17/TH1 and regulatory $\mathrm{T}$ cells. J Allergy Clin Immunol 126(2):280-289

91. Dubois B, Chapat L, Goubier A, Papiernik M, Nicolas JF, Kaiserlian D (2003) Innate $\mathrm{CD} 4{ }^{+} \mathrm{CD} 25^{+}$regulatory $\mathrm{T}$ cells are required for oral tolerance and inhibition of $\mathrm{CD}^{+} \mathrm{T}$ cells mediating skin inflammation. Blood 102(9):3295-3301

92. Ring S, Enk AH, Mahnke K (2010) ATP activates regulatory T cells in vivo during contact hypersensitivity reactions. J Immunol 184(7):3408-3416

93. Honda T, Otsuka A, Tanizaki H, Minegaki Y, Nagao K, Waldmann H, Tomura M, Hori S, Miyachi Y, Kabashima K (2011) Enhanced murine contact hypersensitivity by depletion of endogenous regulatory $\mathrm{T}$ cells in the sensitization phase. J Dermatol Sci 61(2):144-147

94. Ring S, Schafer SC, Mahnke K, Lehr HA, Enk AH (2006) CD4 ${ }^{+}$ $\mathrm{CD}^{2} 5^{+}$regulatory $\mathrm{T}$ cells suppress contact hypersensitivity reactions by blocking influx of effector $\mathrm{T}$ cells into inflamed tissue. Eur J Immunol 36(11):2981-2992

95. Ring S, Oliver SJ, Cronstein BN, Enk AH, Mahnke K (2009) $\mathrm{CD} 4{ }^{+} \mathrm{CD} 25^{+}$regulatory $\mathrm{T}$ cells suppress contact hypersensitivity reactions through a CD39, adenosine-dependent mechanism. J Allergy Clin Immunol 123(6):1287-1296

96. Tomura M, Honda T, Tanizaki H, Otsuka A, Egawa G, Tokura Y, Waldmann H, Hori S, Cyster JG, Watanabe T, Miyachi Y, Kanagawa O, Kabashima K (2010) Activated regulatory T cells are the major $\mathrm{T}$ cell type emigrating from the skin during a cutaneous immune response in mice. J Clin Invest 120(3):883893 
97. Martin SF, Esser PR, Weber FC, Jakob T, Freudenberg MA, Schmidt M, Goebeler M (2011) Mechanisms of chemicalinduced skin inflammation in allergic contact dermatitis. Allergy 66(9):1152-1163

98. Weber FC, Esser PR, Muller T, Ganesan J, Pellegatti P, Simon MM, Zeiser R, Idzko M, Jakob T, Martin SF (2010) Lack of the purinergic receptor $\mathrm{P} 2 \mathrm{X}(7)$ results in resistance to contact hypersensitivity. J Exp Med 207(12):2609-2619

99. Watanabe H, Gaide O, Pétrilli V, Martinon F, Contassot E, Roques S, Kummer JA, Tschopp J, French LE (2007) Activation of the IL- $1 \beta$-processing inflammasome is involved in contact hypersensitivity. J Invest Dermatol 127(8):1956-1963

100. Martinon F, Tschopp J (2004) Inflammatory caspases: linking an intracellular innate immune system to autoinflammatory diseases. Cell 117(5):561-574

101. Mariathasan S, Monack DM (2007) Inflammasome adaptors and sensors: intracellular regulators of infection and inflammation. Nat Rev Immunol 7(1):31-40

102. Church LD, Cook GP, McDermott MF (2008) Primer: inflammasomes and interleukin 1beta in inflammatory disorders. Nat Clin Pract Rheumatol 4(1):34-42

103. Martin SF, Dudda JC, Bachtanian E, Lembo A, Liller S, Dürr C, Heimesaat MM, Bereswill S, Fejer G, Vassileva R, Jakob T, Freudenberg N, Termeer CC, Johner C, Galanos C, Freudenberg MA (2008) Toll-like receptor and IL-12 signaling control susceptibility to contact hypersensitivity. J Exp Med 205(9):21512162

104. Schmidt M, Raghavan B, Muller V, Vogl T, Fejer G, Tchaptchet S, Keck S, Kalis C, Nielsen PJ, Galanos C, Roth J, Skerra A, Martin SF, Freudenberg MA, Goebeler M (2010) Crucial role for human Toll-like receptor 4 in the development of contact allergy to nickel. Nat Immunol 11(9):814-819

105. Chatila TA, Li N, Garcia-Lloret M, Kim HJ, Nel AE (2008) T-cell effector pathways in allergic diseases: transcriptional mechanisms and therapeutic targets. J Allergy Clin Immunol 121(4):812-823

106. Ade N, Leon F, Pallardy M, Peiffer JL, Kerdine-Romer S, Tissier MH, Bonnet PA, Fabre I, Ourlin JC (2009) HMOX1 and NQO1 genes are upregulated in response to contact sensitizers in dendritic cells and THP-1 cell line: role of the Keap1/Nrf2 pathway. Toxicol Sci 107(2):451-460

107. Kissenpfennig A, Henri S, Dubois B, Laplace-Builhé C, Perrin P, Romani N, Tripp CH, Douillard P, Leserman L, Kaiserlian D, Saeland S, Davoust J, Malissen B (2005) Dynamics and function of Langerhans cells in vivo: dermal dendritic cells colonize lymph node areas distinct from slower migrating Langerhans cells. Immunity 22(5):643-654

108. Wang L, Bursch LS, Kissenpfennig A, Malissen B, Jameson SC, Hogquist KA (2008) Langerin expressing cells promote skin immune responses under defined conditions. J Immunol 180(7): $4722-4727$

109. Kaplan DH, Jenison MC, Saeland S, Shlomchik WD, Shlomchik MJ (2005) Epidermal Langerhans cell-deficient mice develop enhanced contact hypersensitivity. Immunity 23(6):611-620

110. Wakem P, Burns RP Jr, Ramirez F, Zlotnick D, Ferbel B, Haidaris CG, Gaspari AA (2000) Allergens and irritants transcriptionally upregulate CD80 gene expression in human keratinocytes. J Invest Dermatol 114(6):1085-1092

111. Burns R, Luzina I, Nasir A, Haidaris CG, Barth RK, Gaspari AA (2005) Keratinocyte-derived, CD80-mediated costimulation is associated with hapten-specific IgE production during contact hypersensitivity to $\mathrm{TH} 1$ haptens. J Allergy Clin Immunol 115(2):383-390

112. Gaspari AA, Burns R, Nasir A, Ramirez D, Barth RK, Haidaris CG (1998) CD86 (B7-2), but not CD80 (B7-1), expression in the epidermis of transgenic mice enhances the immunogenicity of primary cutaneous Candida albicans infections. Infect Immun 66(9):4440-4449

113. Dickel H, Gambichler T, Kamphowe J, Altmeyer P, Skrygan M (2010) Standardized tape stripping prior to patch testing induces upregulation of Hsp90, Hsp70, IL-33, TNF-alpha and IL-8/ CXCL8 mRNA: new insights into the involvement of 'alarmins'. Contact Dermat 63(4):215-222

114. Haraldsen G, Balogh J, Pollheimer J, Sponheim J, Kuchler AM (2009) Interleukin-33-cytokine of dual function or novel alarmin? Trends Immunol 30(5):227-233

115. Carriere V, Roussel L, Ortega N, Lacorre DA, Americh L, Aguilar L, Bouche G, Girard JP (2007) IL-33, the IL-1-like cytokine ligand for ST2 receptor, is a chromatin-associated nuclear factor in vivo. Proc Natl Acad Sci USA 104(1):282-287

116. Komai-Koma M, Gilchrist DS, McKenzie AN, Goodyear CS, Xu D, Liew FY (2011) IL-33 activates B1 cells and exacerbates contact sensitivity. J Immunol 186(4):2584-2591

117. Ali S, Huber M, Kollewe C, Bischoff SC, Falk W, Martin MU (2007) IL-1 receptor accessory protein is essential for IL-33induced activation of T lymphocytes and mast cells. Proc Natl Acad Sci USA 104(47):18660-18665

118. Chackerian AA, Oldham ER, Murphy EE, Schmitz J, Pflanz S, Kastelein RA (2007) IL-1 receptor accessory protein and ST2 comprise the IL-33 receptor complex. J Immunol 179(4):25512555

119. Schmitz J, Owyang A, Oldham E, Song Y, Murphy E, McClanahan TK, Zurawski G, Moshrefi M, Qin J, Li X, Gorman DM, Bazan JF, Kastelein RA (2005) IL-33, an interleukin-1-like cytokine that signals via the IL-1 receptor-related protein ST2 and induces $\mathrm{T}$ helper type 2-associated cytokines. Immunity 23(5):479-490

120. Campos RA, Szczepanik M, Itakura A, Akahira-Azuma M, Sidobre S, Kronenberg M, Askenase PW (2003) Cutaneous immunization rapidly activates liver invariant Valpha14 NKT cells stimulating B-1 B cells to initiate $\mathrm{T}$ cell recruitment for elicitation of contact sensitivity. J Exp Med 198(12):1785-1796

121. Itakura A, Szczepanik M, Campos RA, Paliwal V, Majewska M, Matsuda H, Takatsu K, Askenase PW (2005) An hour after immunization peritoneal B-1 cells are activated to migrate to lymphoid organs where within 1 day they produce IgM antibodies that initiate elicitation of contact sensitivity. J Immunol 175(11):7170-7178

122. Campos RA, Szczepanik M, Lisbonne M, Itakura A, Leite-deMoraes M, Askenase PW (2006) Invariant NKT cells rapidly activated via immunization with diverse contact antigens collaborate in vitro with B-1 cells to initiate contact sensitivity. J Immunol 177(6):3686-3694

123. Balato A, Unutmaz D, Gaspari AA (2009) Natural killer T cells: an unconventional T-cell subset with diverse effector and regulatory functions. J Invest Dermatol 129(7):1628-1642

124. Gober MD, Fishelevich R, Zhao Y, Unutmaz D, Gaspari AA (2008) Human natural killer T cells infiltrate into the skin at elicitation sites of allergic contact dermatitis. J Invest Dermatol 128(6):1460-1469

125. Baron JM, Wiederholt T, Heise R, Merk HF, Bickers DR (2008) Expression and function of cytochrome P450-dependent enzymes in human skin cells. Curr Med Chem 15(22):2258 2264

126. Baron JM, Höller D, Schiffer R, Frankenberg S, Neis M, Merk HF, Jugert FK (2001) Expression of multiple cytochrome P450 enzymes and multidrug resistance-associated transport proteins in human skin keratinocytes. J Invest Dermatol 116(4):541-548

127. Schiffer R, Neis M, Holler D, Rodriguez F, Geier A, Gartung C, Lammert F, Dreuw A, Zwadlo-Klarwasser G, Merk H, Jugert F, Baron JM (2003) Active influx transport is mediated by members of the organic anion transporting polypeptide family in 
human epidermal keratinocytes. J Invest Dermatol 120(2):285291

128. Skazik C, Heise R, Bostanci O, Paul N, Denecke B, Joussen S, Kiehl K, Merk HF, Zwadlo-Klarwasser G, Baron JM (2008) Differential expression of influx and efflux transport proteins in human antigen presenting cells. Exp Dermatol 17(9):739-747

129. Kielar D, Kaminski WE, Liebisch G, Piehler A, Wenzel JJ, Möhle C, Heimerl S, Langmann T, Friedrich SO, Böttcher A, Barlage S, Drobnik W, Schmitz G (2003) Adenosine triphosphate binding cassette $(\mathrm{ABC})$ transporters are expressed and regulated during terminal keratinocyte differentiation: a potential role for ABCA7 in epidermal lipid reorganization. J Invest Dermatol 121(3):465-474

130. Skazik C, Heise R, Ott H, Czaja K, Marquardt Y, Merk HF, Baron JM (2011) Active transport of contact allergens in human monocyte-derived dendritic cells is mediated by multidrug resistance related proteins. Arch Biochem Biophys 508(2):212216

131. Ott H, Bergström MA, Heise R, Skazik C, Zwadlo-Klarwasser G, Merk HF, Baron JM, Karlberg AT (2009) Cutaneous metabolic activation of carvoxime, a self-activating, skin-sensitizing prohapten. Chem Res Toxicol 22(2):399-405

132. Karlberg AT, Bergström MA, Börje A, Luthman K, Nilsson JL (2008) Allergic contact dermatitis-formation, structural requirements, and reactivity of skin sensitizers. Chem Res Toxicol 21(1):53-69

133. Lepoittevin JP (2006) Metabolism versus chemical transformation or pro- versus prehaptens? Contact Dermat 54(2):73-74

134. Sköld M, Börje A, Matura M, Karlberg AT (2002) Studies on the autoxidation and sensitizing capacity of the fragrance chemical linalool, identifying a linalool hydroperoxide. Contact Dermat 46(5):267-272

135. Hagvall L, Sköld M, Bråred-Christensson J, Börje A, Karlberg AT (2008) Lavender oil lacks natural protection against autoxidation, forming strong contact allergens on air exposure. Contact Dermat 59(3):143-150

136. Sköld M, Hagvall L, Karlberg AT (2008) Autoxidation of linalyl acetate, the main component of lavender oil, creates potent contact allergens. Contact Dermat 58(1):9-14

137. Bråred Christensson J, Forsstrom $\mathrm{P}$, Wennberg AM, Karlberg AT, Matura M (2009) Air oxidation increases skin irritation from fragrance terpenes. Contact Dermat 60(1):32-40

138. Schnuch A, Uter W, Geier J, Lessmann H, Frosch PJ (2007) Sensitization to 26 fragrances to be labelled according to current European regulation. Results of the IVDK and review of the literature. Contact Dermat 57(1):1-10

139. Kalergis AM, Lopez CB, Becker MI, Diaz MI, Sein J, Garbarino JA, De Ioannes AE (1997) Modulation of fatty acid oxidation alters contact hypersensitivity to urushiols: role of aliphatic chain beta-oxidation in processing and activation of urushiols. J Invest Dermatol 108(1):57-61

140. Elahi EN, Wright Z, Hinselwood D, Hotchkiss SA, Basketter DA, Pease CK (2004) Protein binding and metabolism influence the relative skin sensitization potential of cinnamic compounds. Chem Res Toxicol 17(3):301-310

141. Hagvall L, Bäcktorp C, Svensson S, Nyman G, Börje A, Karlberg AT (2007) Fragrance compound geraniol forms contact allergens on air exposure. Identification and quantification of oxidation products and effect on skin sensitization. Chem Res Toxicol 20(5):807-814

142. Hagvall L, Baron JM, Börje A, Weidolf L, Merk H, Karlberg AT (2008) Cytochrome P450-mediated activation of the fragrance compound geraniol forms potent contact allergens. Toxicol Appl Pharmacol 233(2):308-313

143. Bergström MA, Ott H, Carlsson A, Neis M, Zwadlo-Klarwasser G, Jonsson CAM, Merk HF, Karlberg A-T, Baron JM (2006) A skin-like cytochrome P450 cocktail activates prohaptens to contact allergenic metabolites. J Invest Dermatol 127(5):11451153

144. Cumberbatch M, Kimber I (1992) Dermal tumour necrosis factor-a induces dendritic cell migration to draining lymph nodes, and possibly provides one stimulus for Langerhans' cell migration. Immunology 75(2):257-263

145. Griffiths CE, Dearman RJ, Cumberbatch M, Kimber I (2005) Cytokines and Langerhans cell mobilisation in mouse and man. Cytokine 32(2):67-70

146. Antonopoulos C, Cumberbatch M, Mee JB, Dearman RJ, Wei XQ, Liew FY, Kimber I, Groves RW (2008) IL-18 is a key proximal mediator of contact hypersensitivity and allergeninduced Langerhans cell migration in murine epidermis. J Leukoc Biol 83(2):361-367

147. Mutyambizi K, Berger CL, Edelson RL (2009) The balance between immunity and tolerance: the role of Langerhans cells. Cell Mol Life Sci 66(5):831-840

148. Toebak MJ, Gibbs S, Bruynzeel DP, Scheper RJ, Rustemeyer T (2009) Dendritic cells: biology of the skin. Contact Dermat 60(1):2-20

149. Kimber I, Weisenberger C (1989) A murine local lymph node assay for the identification of contact allergens: assay development and results of an initial validation study. Arch Toxicol 63(4):274-282

150. OECD (2002) OECD guideline 429 for skin sensitisation. OECD Publishing, Paris

151. Gerberick FG, Ryan CA, Dearman RJ, Kimber I (2007) Local lymph node assay (LLNA) for detection of sensitization capacity of chemicals. Methods 41(1):54-60

152. Hilton J, Dearman RJ, Harvey P, Evans P, Basketter DA, Kimber I (1998) Estimation of relative skin sensitizing potency using the local lymph node assay: a comparison of formaldehyde with glutaraldehyde. Am J Contact Dermat 9(1):29-33

153. European Parliament and Council Directive 1272/2008/EC (2008). Off J Eur Union L-353:1-1355

154. Magnusson B, Kligman AM (1969) The identification of contact allergens by animal assay. The guinea pig maximization test. J Invest Dermatol 52(3):268-276

155. Buehler EV (1965) Delayed dontact hypersensitivity in the Guinea Pig. Arch Dermatol 91:171-177

156. Basketter DA, McFadden JF, Gerberick F, Cockshott A, Kimber I (2009) Nothing is perfect, not even the local lymph node assay: a commentary and the implications for REACH. Contact Dermat 60(2):65-69

157. Landsteiner K, Jacobs J (1936) Studies on the sensitization of animals with simple chemical compounds. II. J Exp Med 64(4):625-639

158. Franot C, Benezra C, Lepoittevin JP (1993) Synthesis and interaction studies of ${ }^{13} \mathrm{C}$ labeled lactone derivatives with a model protein using ${ }^{13} \mathrm{C}$ NMR. Bioorg Med Chem 1(5):389-397

159. Franot C, Roberts DW, Smith RG, Basketter DA, Benezra C, Lepoittevin JP (1994) Structure-activity relationships for contact allergenic potential of $\gamma, \gamma$-dimethyl- $\gamma$-butyrolactone derivatives. Chem Res Toxicol 7(3):297-306

160. Patlewicz GY, Wright ZM, Basketter DA, Pease CK, Lepoittevin JP, Arnau EG (2002) Structure-activity relationships for selected fragrance allergens. Contact Dermat 47(4):219-226

161. Patlewicz GY, Basketter DA, Smith Pease CK, Wilson K, Wright ZM, Roberts DW, Bernard G, Arnau EG, Lepoittevin JP (2004) Further evaluation of quantitative structure-activity relationship models for the prediction of the skin sensitization potency of selected fragrance allergens. Contact Dermat 50(2):91-97

162. Gerberick GF, Vassallo JD, Bailey RE, Chaney JG, Morrall SW, Lepoittevin JP (2004) Development of a peptide reactivity assay for screening contact allergens. Toxicol Sci 81(2):332-343 
163. Gerberick GF, Vassallo JD, Foertsch LM, Price BB, Chaney JG, Lepoittevin JP (2007) Quantification of chemical peptide reactivity for screening contact allergens: a classification tree model approach. Toxicol Sci 97(2):417-427

164. Jacobs JJ, Lehe CL, Cammans KD, Das PK, Elliott GR (2004) Assessment of contact allergens by dissociation of irritant and sensitizing properties. Toxicol In Vitro 18(5):681-690

165. Lehé CL, Jacobs JJ, Hua CM, Courtellemont P, Elliott GR, Das PK (2006) Subtoxic concentrations of allergenic haptens induce LC migration and maturation in a human organotypic skin explant culture model: a novel method for identifying potential contact allergens. Exp Dermatol 15(6):421-431

166. Sallusto F, Lanzavecchia A (1994) Efficient presentation of soluble antigen by cultured human dendritic cells is maintained by granulocyte/macrophage colony-stimulating factor plus interleukin 4 and downregulated by tumor necrosis factor $\alpha$. J Exp Med 179(4):1109-1118

167. Toebak MJ, Pohlmann PR, Sampat-Sardjoepersad SC, von Blomberg BME, Bruynzeel DP, Scheper RJ, Rustemeyer T, Gibbs S (2006) CXCL8 secretion by dendritic cells predicts contact allergens from irritants. Toxicol In Vitro 20(1):117-124

168. Ott H, Wiederholt T, Bergstrom MA, Heise R, Skazik C, Czaja K, Marquardt Y, Karlberg AT, Merk HF, Baron JM (2010) High-resolution transcriptional profiling of chemical-stimulated dendritic cells identifies immunogenic contact allergens, but not prohaptens. Skin Pharmacol Physiol 23(4):213-224

169. Hooyberghs J, Schoeters E, Lambrechts N, Nelissen I, Witters H, Schoeters G, van den Heuvel R (2008) A cell-based in vitro alternative to identify skin sensitizers by gene expression. Toxicol Appl Pharmacol 231(1):103-111

170. Lambrechts N, Vanheel H, Nelissen I, Witters H, van den Heuvel R, van Tendeloo V, Schoeters G, Hooyberghs J (2010) Assessment of chemical skin-sensitizing potency by an in vitro assay based on human dendritic cells. Toxicol Sci 116(1):122129

171. Johansson H, Lindstedt M, Albrekt AS, Borrebaeck CA (2011) A genomic biomarker signature can predict skin sensitizers using a cell-based in vitro alternative to animal tests. BMC Genomics 12(1):399 (Epub ahead of print)

172. Ade N, Martinozzi-Teissier S, Pallardy M, Rousset F (2006) Activation of U937 cells by contact sensitizers: CD86 expression is independent of apoptosis. J Immunotoxicol 3(4):189-197

173. Python F, Goebel C, Aeby P (2007) Assessment of the U937 cell line for the detection of contact allergens. Toxicol Appl Pharmacol 220(2):113-124

174. Ashikaga T, Yoshida Y, Hirota M, Yoneyama K, Itagaki H, Sakaguchi H, Miyazawa M, Ito Y, Suzuki H, Toyoda H (2006) Development of an in vitro skin sensitization test using human cell lines: the human Cell Line Activation Test (h-CLAT). I. Optimization of the h-CLAT protocol. Toxicol In Vitro 20(5):767-773

175. Sakaguchi H, Ashikaga T, Miyazawa M, Yoshida Y, Ito $Y$, Yoneyama K, Hirota M, Itagaki H, Toyoda H, Suzuki H (2006) Development of an in vitro skin sensitization test using human cell lines; human Cell Line Activation Test (h-CLAT). II. An inter-laboratory study of the h-CLAT. Toxicol In Vitro 20(5):774-784

176. Maxwell G, Aeby P, Ashikaga T, Bessou-Touya S, Diembeck W, Gerberick F, Kern P, Marrec-Fairley M, Ovigne JM, Sakaguchi $\mathrm{H}$, Schroeder K, Tailhardat M, Teissier S, Winkler P (2011) Skin sensitisation: the Colipa strategy for developing and evaluating non-animal test methods for risk assessment. ALTEX 28(1):50-55

177. Ball N, Cagen S, Carrillo JC, Certa H, Eigler D, Emter R, Faulhammer F, Garcia C, Graham C, Haux C, Kolle SN, Kreiling R, Natsch A, Mehling A (2011) Evaluating the sensitization potential of surfactants: integrating data from the local lymph node assay, guinea pig maximization test, and in vitro methods in a weight-of-evidence approach. Regul Toxicol Pharmacol 60(3):389-400

178. Sinigaglia F, Scheidegger D, Garotta G (1985) Isolation and characterization of $\mathrm{Ni}$-specific $\mathrm{T}$ cell clones from patients with Ni-contact dermatitis. J Immunol 135(6):3929-3932

179. Ade N, Antonios D, Kerdine-Romer S, Boisleve F, Rousset F, Pallardy M (2007) NF- $\kappa$ B plays a major role in the maturation of human dendritic cells induced by $\mathrm{NiSO}_{4}$ but not by DNCB. Toxicol Sci 99(2):488-501

180. Veldhoen M, Uyttenhove C, van Snick J, Helmby H, Westendorf A, Buer J, Martin B, Wilhelm C, Stockinger B (2008) Transforming growth factor- $\beta$ 'reprograms' the differentiation of $\mathrm{T}$ helper 2 cells and promotes an interleukin 9-producing subset. Nat Immunol 9(12):1341-1346

181. Dardalhon V, Awasthi A, Kwon H, Galileos G, Gao W, Sobel RA, Mitsdoerffer M, Strom TB, Elyaman W, Ho IC, Khoury S, Oukka M, Kuchroo VK (2008) IL-4 inhibits TGF- $\beta$-induced Foxp3 + T cells and, together with TGF- $\beta$, generates IL-9 + IL-10 + Foxp3 - effector T cells. Nat Immunol 9(12):13471355

182. Duhen T, Geiger R, Jarrossay D, Lanzavecchia A, Sallusto F (2009) Production of interleukin 22 but not interleukin 17 by a subset of human skin-homing memory $\mathrm{T}$ cells. Nat Immunol 10(8):857-863

183. Trifari S, Kaplan CD, Tran EH, Crellin NK, Spits H (2009) Identification of a human helper $\mathrm{T}$ cell population that has abundant production of interleukin 22 and is distinct from $\mathrm{T}(\mathrm{H})$ 17, $\mathrm{T}(\mathrm{H}) 1$ and $\mathrm{T}(\mathrm{H}) 2$ cells. Nat Immunol 10(8):864-871

184. Fuhlbrigge RC, King SL, Sackstein R, Kupper TS (2006) CD43 is a ligand for E-selectin on CLA+ human T cells. Blood 107(4):1421-1426

185. Alcaide P, King SL, Dimitroff CJ, Lim YC, Fuhlbrigge RC, Luscinskas FW (2007) The 130-kDa glycoform of CD43 functions as an E-selectin ligand for activated Th1 cells in vitro and in delayed-type hypersensitivity reactions in vivo. J Invest Dermatol 127(8):1964-1972

186. Martin SF, Esser PR, Schmucker S, Dietz L, Naisbitt DJ, Park BK, Vocanson M, Nicolas JF, Keller M, Pichler WJ, Peiser M, Luch A, Wanner R, Maggi E, Cavani A, Rustemeyer T, Richter A, Thierse HJ, Sallusto F (2010) T-cell recognition of chemicals, protein allergens and drugs: towards the development of in vitro assays. Cell Mol Life Sci 67(24):4171-4184

187. Vocanson M, Cluzel-Tailhardat M, Poyet G, Valeyrie M, Chavagnac C, Levarlet B, Courtellemont P, Rozieres A, Hennino A, Nicolas JF (2008) Depletion of human peripheral blood lymphocytes in $\mathrm{CD} 25^{+}$cells allows for the sensitive in vitro screening of contact allergens. J Invest Dermatol 128(8):2119-2122

188. Vocanson M, Hennino A, Rozieres A, Cluzel-Tailhardat M, Poyet G, Valeyrie M, Benetiere J, Tedone R, Kaiserlian D, Nicolas JF (2009) Skin exposure to weak and moderate contact allergens induces IFN $\gamma$ production by lymph node cells of $\mathrm{CD}^{+}$ T-cell-depleted mice. J Invest Dermatol 129(5):1185-1191

189. Aliahmadi E, Gramlich R, Grutzkau A, Hitzler M, Kruger M, Baumgrass R, Schreiner M, Wittig B, Wanner R, Peiser M (2009) TLR2-activated human langerhans cells promote Th17 polarization via IL-1 $\beta$, TGF- $\beta$ and IL-23. Eur J Immunol 39(5):1221-1230

190. Nakae S, Komiyama Y, Nambu A, Sudo K, Iwase M, Homma I, Sekikawa K, Asano M, Iwakura Y (2002) Antigen-specific T cell sensitization is impaired in Il-17-deficient mice, causing suppression of allergic cellular and humoral responses. Immunity $17(3): 375-387$

191. He D, Wu L, Kim HK, Li H, Elmets CA, Xu H (2006) CD8 + IL-17-producing $\mathrm{T}$ cells are important in effector 
functions for the elicitation of contact hypersensitivity responses. J Immunol 177(10):6852-6858

192. Albanesi C, Scarponi C, Cavani A, Federici M, Nasorri F, Girolomoni $\mathrm{G}$ (2000) Interleukin-17 is produced by both Th1 and Th2 lymphocytes, and modulates interferon- $\gamma$ - and interleukin4- induced activation of human keratinocytes. J Invest Dermatol 115(1):81-87

193. O’Leary JG, Goodarzi M, Drayton DL, von Andrian UH (2006) $\mathrm{T}$ cell- and $\mathrm{B}$ cell-independent adaptive immunity mediated by natural killer cells. Nat Immunol 7(5):507-516

194. Paust S, Gill HS, Wang BZ, Flynn MP, Moseman EA, Senman B, Szczepanik M, Telenti A, Askenase PW, Compans RW, von Andrian UH (2010) Critical role for the chemokine receptor CXCR6 in NK cell-mediated antigen-specific memory of haptens and viruses. Nat Immunol 11(12):1127-1135

195. Carbone T, Nasorri F, Pennino D, Eyerich K, Foerster S, Cifaldi L, Traidl-Hoffman C, Behrendt H, Cavani A (2010) $\mathrm{CD} 56^{\text {high }} \mathrm{CD} 16^{-} \mathrm{CD} 62 \mathrm{~L}^{-} \mathrm{NK}$ cells accumulate in allergic contact dermatitis and contribute to the expression of allergic responses. J Immunol 184(2):1102-1110

196. de Jong WH, van Och FMM, Hartog Jager CF, Spiekstra SW, Slob W, Vandebriel RJ, van Loveren H (2002) Ranking of allergenic potency of rubber chemicals in a modified local lymph node assay. Toxicol Sci 66(2):226-232

197. Friedmann PS, Moss C, Shuster S, Simpson JM (1983) Quantitative relationships between sensitizing dose of DNCB and reactivity in normal subjects. Clin Exp Immunol 53(3):709-715

198. van Och FMM, Vandebriel RJ, de Jong WH, van Loveren H (2003) Effect of prolonged exposure to low antigen concentration for sensitization. Toxicology 184(1):23-30

199. de Jong WH, de Klerk A, Beek MT, Veenman C, van Loveren H (2007) Effect of prolonged repeated exposure to formaldehyde donors with doses below the EC3 value on draining lymph node responses. J Immunotoxicol 4(3):239-246
200. Kimber I, Agius R, Basketter DA, Corsini E, Cullinan P, Dearman RJ, Gimenez-Arnau E, Greenwell L, Hartung T, Kuper F, Maestrelli P, Roggen E, Rovida C, Casati S (2007) Chemical respiratory allergy: opportunities for hazard identification and characterisation. Alternat Lab Anim 35(2):243-265

201. Arts JHE, de Jong WH, van Triel JJ, Schijf MA, de Klerk A, van Loveren H, Kuper CF (2008) The respiratory local lymph node assay as a tool to study respiratory sensitizers. Toxicol Sci 106(2):423-434

202. Gerberick GF, Robinson MK, Felter SP, White IR, Basketter DA (2001) Understanding fragrance allergy using an exposurebased risk assessment approach. Contact Dermat 45(6):333-340

203. Api AM, Basketter DA, Cadby PA, Cano MF, Ellis G, Gerberick GF, Griem P, McNamee PM, Ryan CA, Safford R (2008) Dermal sensitization quantitative risk assessment (QRA) for fragrance ingredients. Regul Toxicol Pharmacol 52(1):3-23

204. European Parliament and Council Directive 648/2004/EC (2004). Off J Eur Union L-104:1-35

205. Scientific Committee on Consumer Products-Opinion on methyldibromo glutaronitrile (2005). SCCP 0863/05

206. Scientific Committee on Consumer Products-Memorandum on hair dye substances and their skin sensitising properties (2006). SCCP

207. Scientific Committee on Consumer Products - Opinion on sensitivity to hair dyes, consumer self testing (2007). SCCP

208. European Parliament and Council Directive 2003/15/EC (2003). Off J Eur Union L-66:26-35

209. Menne T, Wahlberg JE (2002) Risk assessment failures of chemicals commonly used in consumer products. Contact Dermat 46(4):189-190

210. Jadassohn J (1896 1895) Zur Kenntnis der medikamentösen Dermatosen. In: Braunmüller W (ed) Verhandlungen der Deutschen Dermatologischen Gesellschaft. Fünfter Kongreß., Wien, pp 129-143 